\title{
1 Evaluation of Meteoric Calcite Cements as a Proxy for Mass-47 Clumped Isotope \\ 2 Thermometry
}

3 William F. Defliese $e^{\mathrm{a}, 1^{*}}$

4 Kyger C. Lohmann ${ }^{\mathrm{a}}$

5 a. Department of Earth and Environmental Sciences, University of Michigan, Ann Arbor, $6 \quad$ MI

1. Present Address: Department of Earth, Planetary, and Space Sciences, University of California, Los Angeles, CA.

*. Corresponding Author: defliese@epss.ucla.edu

\section{Abstract}

Meteoric diagenetic cements are ubiquitous throughout geologic history, affecting most carbonate exposures worldwide. They can often be difficult to interpret, as it is usually difficult to separate the influences of water $\delta^{18} \mathrm{O}$ and temperature on isotopic signals contained within the carbonate rock body. Despite this difficulty in interpretation, meteoric phreatic cements can potentially be a useful proxy material, as they form slowly in equilibrium at mean annual temperature and are not affected by any biogenic effects that can bias other proxy materials.

We applied the mass-47 clumped isotope paleothermometer to Pleistocene and Holocene carbonates from Bermuda and Barbados in order to investigate the effects of meteoric diagenesis on $\Delta_{47}$ signals, and to determine their suitability as a paleotemperature proxy. Phreatic calcite cements are found to record the same temperatures as unaltered carbonate sediments, while any sample exhibiting vadose characteristics is biased towards unreasonably hot apparent formation temperatures. Burial heating and requilibration are not geologically viable explanations for the anomalously hot temperatures recorded in vadose cements, as neither Bermuda or Barbados has any burial history. Instead, it is likely that precipitation in the vadose zone occurs on timescales quicker than isotopic equilibrium can be achieved, driven by a combination of $\mathrm{CO}_{2}$ degassing and evaporation, which have been previously shown to cause problems in speleothems and pedogenic carbonates. 
We conclude by suggesting that meteoric phreatic calcites may be an ideal phase for paleotemperature reconstruction, as they accurately record mean annual temperatures and form under equilibrium conditions, while also being immune to further mineral driven diagenesis. Vadose cements, and any sample likely affected by processes similar to vadose diagenesis, should be avoided for climate reconstructions using the mass-47 clumped isotope thermometer.

\section{Introduction}

The mass-47 clumped isotope paleothermometer (denoted as $\Delta_{47}$ ) is a recent innovation that allows independent measurement of the formation temperature of carbonate materials (Ghosh et al., 2006). It is increasing applied to a variety of problems where independent confirmation of the $\delta^{18} \mathrm{O}$ of the precipitating fluid is difficult or unavailable, which precludes accurate reconstructions of depositional environment and history. With a single measurement, clumped isotopes offer the ability to reconstruct the sample's temperature of formation, $\delta^{18} \mathrm{O}$ and $\delta^{13} \mathrm{C}$, and the $\delta^{18} \mathrm{O}$ of formation waters (Ghosh et al., 2006; Eiler, 2007; Eiler, 2011). A natural application of this technique is studies of meteoric and burial diagenesis, where the influences of temperature and $\delta^{18} \mathrm{O}$ of diagenetic fluids moving through the system are difficult to separate (Bergman et al., 2013; Budd et al., 2013; Loyd et al., 2013; Huntington and Lechler, 2015), particularly in the absence of additional constraints such as fluid inclusions. Clumped isotopes can potentially resolve these issues, which would greatly advance the study of diagenetic systems (Swart, 2015).

In this study, carbonate cements forming within the meteoric diagenetic environment are examined to evaluate the degree to which they record and preserve information about the environment in which they formed. Meteoric carbonates are of particular interest because they form at or very near to the Earth's surface, and thus have the potential of providing a unique record of past climate conditions. Meteoric diagenesis takes place primarily in two formation zones: the vadose zone, which occurs above the water table and is a zone of periodic wetting and water transport; and the phreatic zone, which is located below the water table and is constantly saturated with water (James and Choquette, 1990). These two zones have disparate modes of dissolution and cementation. The vadose zone is characterized by water controlled dissolution, where the saturation state of formation waters moving through the rock body controls carbonate dissolution and precipitation of low-Mg calcite cements (James and Choquette, 1990). The 
phreatic zone is characterized by mineral controlled dissolution and precipitation, where metastable mineralogies such as aragonite and high-Mg calcite are dissolved and replaced by more stable minerals such as low-Mg calcite (James and Choquette, 1990). These processes leave behind distinctive crystal morphologies and characteristics in thin section analysis of the carbonate rock body (Figure 1), which allows for determination of the type of diagenesis affecting a particular sample.

Several characteristics of meteoric phreatic cements make them particularly promising as a proxy of mean annual temperature via clumped isotope analysis. These cements form below the water table, and are buffered from temperature excursions by the large heat capacity of the host water-saturated rock. Meteoric phreatic calcite precipitates slowly in its environment, and is not subjected to excursions in precipitation rate caused by temperature changes, evaporation, or $\mathrm{CO}_{2}$ degassing, all of which may cause departures from isotopic equilibrium during precipitation. Additionally meteoric phreatic calcite is formed of stable low-Mg calcite, which is resistant to further mineralogically controlled diagenesis, unlike many primary materials such as aragonitic bivalves or even high-Mg calcite. As such, it may be an ideal phase for reconstructing mean annual temperatures, and clumped isotope analysis of meteoric diagenetic phases may additionally shed light on several of the existing well documented departures from equilibrium documented in $\Delta_{47}$ studies of pedogenic carbonates and speleothems, both of which form in environments analogous to the vadose zone. Here we use coexisting unaltered host rock and rocks altered by both phreatic and vadose diagenesis from Pleistocene to Holocene deposits in Bermuda and Barbados to evaluate the effects of meteoric diagenesis on $\Delta_{47}$ signals, and to examine their potential as a paleotemperature proxy.

\section{Geologic Setting}

Bermuda and Barbados are two seamounts capped by extensive carbonate forming reefs which comprise most of the exposures above sea level in both island complexes. Both of these locations have extensive well-documented Pleistocene to recent meteoric diagenetic cements occurring in host rocks throughout the islands. These islands also allow us to eliminate burial reheating and the possibility of re-equilibration of $\Delta_{47}$ signals as a variable in our analysis (Passey et al., 2012; Henkes et al., 2014), as neither one has experienced any burial since their formation. Burial re-equilibration in response to increased temperature has been suggested as a 
possible mechanism for some of the elevated temperatures reported from prior $\Delta_{47}$ studies (Passey and Henkes, 2012; Henkes et al., 2014; Shenton et al., 2015); our choice of field locations allows us to solely focus on formation temperatures and equilibrium relations without additional complicating factors.

Barbados $\left(15^{\circ} 10^{\prime} \mathrm{N}, 59^{\circ} 30^{\prime} \mathrm{W}\right)$ has been continually tectonically uplifted throughout the Pleistocene, producing a series of coral reef terraces corresponding to successive highstands, lowstands are not well represented (Schellmann and Radtke, 2004). Sampling on Barbados focused on host rocks of marine isotopic stages (MIS) 5e, 9, and 11 in age. The corresponding cements are of an age equal to or younger than the host rocks. All Barbados samples are completely recrystallized, and no original grains are visible. These samples likely reflect $100 \%$ phreatic diagenesis (Allan and Matthews, 1982).

Bermuda $\left(32^{\circ} 18^{\prime} \mathrm{N}, 64^{\circ} 45^{\prime} \mathrm{W}\right)$ has an unusual geologic history for a carbonate island that has required multiple revisions to the depositional model and ages of the various units (Figure 4.2, see Vacher et al., 1995, and sources within for a full description). Most exposed rocks in Bermuda consist of eolianite, a wind deposited carbonate sandstone made of algal and other carbonate allochems that is intercalculated with paleosols formed during sea level lowstands. Locally, beach deposits are present in some locations. The current depositional model for Bermuda suggests that carbonate primary production reaches a maximum during interglacial highstands, and that large carbonate sand dunes form to create the interior regions of Bermuda (Vacher et al., 1995; Vacher and Rowe, 1997). Subsequent diagenesis and calcite cementation lithifies the dunes in place, forming spectacular outcrops of eolianite. The depositional pattern does not produce the 'layer cake' structure that might be expected in subaqueously deposited sediments, but rather a combination of laterally prograding onlapping dune and beach structures that are separated by red soil zones (paleosols) corresponding to glacial intervals and relative sea level lowstands. Many stratigraphic units are missing from individual outcrops, complicating initial efforts to construct a coherent stratigraphy and to assign depositional ages (Land et al., 1967; Vacher et al., 1995; Vacher and Rowe, 1997). This depositional model also implies that all grains contained within a formation predate that formation, which means that the temperature they record does not represent the time of deposition but an amalgamation of time periods preceding it. Given this, and the fact that current 
mean annual temperature in Bermuda is the highest it has been since at least MIS 5e (Sachs and Lehman, 1999; Lehman et al., 2002), temperatures recorded in host rock in Bermuda are expected to be colder than present.

Diagenetic cements can be used to constrain relative sea level in Bermuda by noting their formation above or below the water table (Meischner et al., 1995). Bermuda has a very simple hydrological system, with all precipitation immediately infiltrating into host rock down to sea level (Rowe, 1984). Currently there are no streams or elevated water tables in Bermuda, and it is unlikely that such features were significant in the past. The only way to raise the water table and associated freshwater lenses is to raise the relative sea level, so the existence of meteoric phreatic cements at elevations above current sea level has been used by previous authors to constrain minimum sea level rises at times in the past (Meischner et al., 1995; Vollbrecht and Meischner, 1996). All of our samples come from sections that are at or above current sea level, so they are not subjected to current phreatic diagenesis which might complicate our temperature reconstructions.

Bermuda samples span host rocks of MIS 13 (or older) to modern beach sands (Vacher et al., 1995; Vacher and Rowe, 1997). Host rocks of all interglacial episodes except MIS 3 are present in our sampling. Lowstand sequences are presently below sea level, and were not sampled. Bermuda samples are not as well cemented as Barbados samples, and all rocks contain a significant amount of original material. Both vadose and phreatic cements are present in Bermuda rocks, some rocks containing only one mode of diagenesis while others contain both.

\section{Methods}

Hand samples were taken by use of rock hammer and chisels for all well cemented rocks. Samples were cleaned with deionized $\mathrm{H}_{2} \mathrm{O}$, and then cut into slabs to allow access to unweathered surfaces. One surface of the slab was bulk sampled by a dental drill at low speed setting for $\Delta_{47}$ analysis, the other surface was used to make thin sections for petrographic and high resolution stable isotope analysis. Barbados samples were not analyzed by thin section, as they were completely crystalline and showed no traces of original grains.

Modern beach sediments were collected and allowed to air dry in the field before being shipped to the laboratory. Once in the lab, they were rinsed with deionized $\mathrm{H}_{2} \mathrm{O}$, and allowed to 
air dry. Foreign (non-carbonate) objects were removed with tweezers before powdering with a mortar and pestle for $\Delta_{47}$ analysis.

$\Delta_{47}$ analysis was performed using a custom built reaction line at the University of Michigan Stable Isotope Laboratory. 4-6 mg of sample powder was digested in a common acid bath using 104 wt. $\% \mathrm{H}_{3} \mathrm{PO}_{4}$ at a temperature of $75{ }^{\circ} \mathrm{C}$. Extracted $\mathrm{CO}_{2}$ was dried by two stages of cryogenic separation at $-95{ }^{\circ} \mathrm{C}$ 1-propanol/Liquid $\mathrm{N}_{2}$ mixture, 4 minute transfer time) to remove $\mathrm{H}_{2} \mathrm{O}$. Dehydrated $\mathrm{CO}_{2}$ was then cleaned using a $\mathrm{U}$ trap filled with PoraPak Q material (Waters Corp., 50-80 mesh). Samples were frozen into a coldfinger upstream of the PoraPak U trap, and allowed to equilibrate for 5 minutes with the PoraPak held at $-30{ }^{\circ} \mathrm{C}$ (Defliese et al., 2015). Liquid $\mathrm{N}_{2}$ was then placed on a coldfinger downstream of the PoraPak trap, and sample $\mathrm{CO}_{2}$ was cryogenically drawn through the trap for 15 minutes without the use of a carrier gas. Yields were checked before and after this step using an electric manometer to ensure total sample recovery during the cleaning process, any samples without complete yields were discarded. Purified $\mathrm{CO}_{2}$ was then transferred to a vial for storage until analysis on the mass spectrometer, and samples were analyzed within 24 hours of extraction.

Samples were analyzed at the University of Michigan Stable Isotope Laboratory using a Thermo-Finnigan MAT 253 dual inlet mass spectrometer that has been specially configured to collect masses 44-49 (Huntington et al., 2009). All samples were replicated a minimum of three times, with most samples replicated four times (with the exception of BB10-29, replicated twice). Analyses were performed in dual inlet mode with the pressure balanced to achieve 16 volts on the mass 44 cup, and measurements for $\delta^{18} \mathrm{O}, \delta^{13} \mathrm{C}$, and $\Delta_{47}$ were taken simultaneously. $\Delta_{47}$ results are normalized to the Universal Reference Frame by use of $\mathrm{CO}_{2}-\mathrm{H}_{2} \mathrm{O}$ equilibration at $25^{\circ} \mathrm{C}$ and heated $\mathrm{CO}_{2}$ at $1000{ }^{\circ} \mathrm{C}$ as described in Dennis et al. (2011). All standard $\mathrm{CO}_{2}$ gases were subject to the same cleaning procedures as sample $\mathrm{CO}_{2}$ gasses to ensure uniformity. $\Delta_{47}$ values were converted into temperatures using the acid fractionation offset and high temperature composite $\Delta_{47}$-temperature calibration of Defliese et al. (2015), which was chosen as it incorporates data from multiple prior calibrations as well as data generated using the same instrument and apparatus used in this study. The choice of calibration does not affect the general conclusions of the study regarding the suitability of diagenetic cements for $\Delta_{47}$-temperature reconstructions. $\Delta_{47}$ temperatures were combined with co-measured $\delta^{18} \mathrm{O}$ to calculate the 
177 oxygen isotopic value of precipitating water using the calcite-water $\delta^{18} \mathrm{O}$ equation of Kim and 178 O’Neil (1997).

179

180

Point counting analysis on thin sections was conducted by scanning images from the thin sections using a digital camera attached to a petrographic microscope in the Electron Beam Microanalysis Laboratory at the University of Michigan. An estimate of the relative abundance of the different carbonate allochems and cement types was tabulated from the images using the program ImageJ. The percent original grains, vadose cements, phreatic cements, and pore spaces for Bermuda samples were calculated from these image scan data, with areas assigned based on visual characteristics such as cement texture. Thin sections were also examined under cathodoluminscence, however none of the samples exhibited any fluorescence or luminescent zonation, which is not surprising as there is no weathering source for luminescing ions in Bermuda.

Individual grains and cements were analyzed for $\delta^{18} \mathrm{O}$ and $\delta^{13} \mathrm{C}$ by microdrilling thin sections with a Merchantek MicroMill computer controlled drilling stage. Approximately $50 \mu \mathrm{g}$ of powder was used for each analysis, and was analyzed using a Kiel III automated carbonate device attached to a Thermo-Finnegan MAT 253 dual inlet mass spectrometer. Data was standardized by comparison to NBS 18 and 19 standards, and is reported in units of per mille (\%o) relative to the VPDB standard.

Mixing calculations were carried out on Bermuda samples to calculate the influence of different cement types on bulk $\Delta_{47}$ values (Defliese and Lohmann, 2015). Briefly, the mixing model of Defliese and Lohmann (2015) is a numerical model that assumes that overall isotopic composition and ${ }^{13} \mathrm{C}-{ }^{18} \mathrm{O}$ bond ordering are linearly conserved when two (or more) end-members are combined to create a mixture. However, while the total number of ${ }^{13} \mathrm{C}-{ }^{18} \mathrm{O}$ bonds in a mixture can be defined by linear mixing of end-members, the stochastic (randomized) distribution of ${ }^{13} \mathrm{C}-{ }^{18} \mathrm{O}$ bonds changes as a function of the bulk isotopic composition, creating offsets in $\Delta_{47}$ values of a mixture that are not representative of the average formation temperatures of the end-members. The mixing model accounts for this by using a system of equations to linearly mix end-member $\delta^{18} \mathrm{O}, \delta^{13} \mathrm{C}$, and total ${ }^{13} \mathrm{C}-{ }^{18} \mathrm{O}$ bonds, and then separately calculates the $\Delta_{47}$ value of the mixture based on these linearly mixed bulk isotopic values. The mixing model can also be used to solve for the $\delta^{18} \mathrm{O}, \delta^{13} \mathrm{C}$, and $\Delta_{47}$ values of an end-member if 
these values are known for all other end-members and the mixture itself, and the percent contribution of each end-member to the mixture is known (Defliese and Lohmann, 2015), in what is essentially a mass-balance approach. We applied this to our data by first using the point counting data to assign percent contributions of each end-member type to each bulk sample. $\Delta_{47}$ measurements from modern beach sediments as well as samples containing $>98 \%$ unaltered grains were used to constrain original grain $\Delta_{47}$ values, and combined with the microsampled end-member $\delta^{18} \mathrm{O}$ and $\delta^{13} \mathrm{C}$ values on individual grains and cements to estimate phreatic and vadose $\Delta_{47}$ values. This was achieved by first estimating a common $\Delta_{47}$ value for phreatic cements using samples that consisted only of replaced original grains (neomorphic replacement) and phreatic components ( $>2 \%$ vadose component), and then applying the estimated $\Delta_{47}$ value to samples that had multiple phases present. Phases of less than $2 \%$ abundance were not considered during mixing calculations, as they exist in such low quantities that attempts to calculate their composition through mass balance yielded implausible results.

\section{Results}

Stable isotope and $\Delta_{47}$ results for Bermuda and Barbados are reported in tables 1 and 2, with full $\Delta_{47}$ including equilibrated gases reported in the supplementary information. $\Delta_{47}$ values are reported as temperatures using the composite calibration of Defliese et al. (2015). Barbados samples record temperatures from 16.3 to $22.2^{\circ} \mathrm{C}$, which fall below the current mean annual temperature of $26.2^{\circ} \mathrm{C}$ (Table 2). Bermuda samples show greater variation, with a minimum temperature of $13.6^{\circ} \mathrm{C}$ and a maximum temperature of $54.4^{\circ} \mathrm{C}$, which significantly exceeds the modern mean annual temperature of $21.6^{\circ} \mathrm{C}$ (Table 1). When combined with point counting results (Table 3), a clear trend in temperature is revealed. Samples that consist of either original grains or phreatic cements, or some combination thereof, fall below current mean annual temperature for both islands. In contrast, any sample exhibiting significant vadose cements ( $>2 \%$ vadose component) displays elevated temperatures that in many cases fall well above current mean annual temperatures or even peak summer temperatures (Figure 3).

Calculated water $\delta^{18} \mathrm{O}$ values for phreatic cements in Barbados fall between $-2.32 \%$ and 4.04\% VSMOW, consistent with meteoric precipitation. Calculated water values for Bermudan samples vary significantly more than Barbados samples, with original cements falling between $0.83 \%$ and $0.35 \%$ VSMOW, consistent with a mix of calcite and aragonite in equilibrium with 
ocean water. Bermudan samples affected by phreatic diagenesis fall between $-3.83 \%$ and $1.77 \%$ VSMOW, which is consistent with meteoric alteration, while samples affected by vadose diagenesis falling between $-1.96 \%$ and 3.92\% VSMOW, with most vadose samples having positive water $\delta^{18} \mathrm{O}$ values.

High resolution subsampling results for Bermuda samples are shown in table 3 , as well as calculated $\Delta_{47}$ values for vadose cement. We calculate an average $\Delta_{47}$ value of $0.7175 \%$ for phreatic cements from samples exhibiting only original and phreatic textures, corresponding to an equilibrium temperature of $16.9{ }^{\circ} \mathrm{C}$. Calculated $\Delta_{47}$ values for vadose components range from $0.5655 \%$ to $-0.0450 \%$, with an average value of $0.3708 \%$, which would correspond to an apparent formation temperature of $361{ }^{\circ} \mathrm{C}$ if interpreted to represent equilibrium conditions. When we only consider samples that have more than $10 \%$ vadose component, the average $\Delta_{47}$ value rises to $0.4235 \%$, which corresponds to an apparent formation temperature of $233{ }^{\circ} \mathrm{C}$ if interpreted to represent equilibrium conditions. Calculated mixing offsets in $\Delta_{47}$ suggest that end member mixing does not play a significant role in most Bermuda samples, with only a few samples containing significant vadose components having offsets exceeding $0.0010 \%$, and none larger than $0.0036 \%$. Our calculations for vadose $\Delta_{47}$ values incorporate these offsets for the samples effected.

\section{Carbonate Petrology, Diagenesis, and Isotope Geochemistry}

\subsection{Barbados}

All Barbados samples are fully crystalline and replaced with sparry calcite, and original textures and components have been completely obliterated. In most cases, there is no remaining outline of original material, though a few samples show neomorphic replacement of coral skeletal structures which are further overgrown with calcite spar. Remaining porosity for most samples is negligible. Thin sections were not made for these rocks, as the objective of this study is to identify the behavior of $\Delta_{47}$ in different types of diagenetic cement, and the Barbados samples are exclusively comprised of meteoric phreatic calcites. There are no significant differences in $\Delta_{47}$ and $\delta^{18} \mathrm{O}$ values between samples of different host rock ages in Barbados, although there are significant differences in $\delta^{13} \mathrm{C}$; however this is consistent with meteoric phreatic diagenesis (Lohmann, 1988; James and Choquette, 1990) 


\subsection{Bermuda}

Bermuda samples were taken at multiple locations on the island (Figure 2), focusing on sections and exposures where diagenetic alteration has been reported by previous authors. We will discuss the petrology by field location and Formation.

\subsubsection{Astwood Park}

The Southampton Formation (MIS 5a) forms large eolianite dunes with foresets up to 5 meters tall in this section, separated by weakly developed protosols rich in land snails. Petrographic analysis of the Southampton Fm. shows that it is very weakly cemented, with 33\% porosity and small quantities (less than $1 \%$ of rock) of vadose menisci at grain contacts (Table 3). Grains do not visually appear to be altered or replaced.

Bulk rock $\Delta_{47}$ measurements from the Southampton at Astwood Park yield an average of $0.725 \%$, or $15.1^{\circ} \mathrm{C}$. Simultaneous measurements of bulk rock $\delta^{18} \mathrm{O}$ and $\delta^{13} \mathrm{C}$ (Figure $4 \mathrm{~A}$ ) show that some components of the rock have been altered from primary marine values, as $\delta^{18} \mathrm{O}$ averages $-0.58 \%$ o VPDB, while $\delta^{13} \mathrm{C}$ is $0.45 \%$ (unaltered values should have $\delta^{18} \mathrm{O}>0 \%$ o, $\delta^{13} \mathrm{C}$ $2 \%$ ). Subsampling of two red algae grains reveals that some of the grains have been replaced and others retain original isotopic values in equilibrium with seawater. Given the lack of dissolution features and precipitated cements within the Southampton, some of the grains that appear altered may be recycled from pre-existing eroded rock allochems that were altered before being incorporated into the Southampton Fm.

In addition to the Southampton section, a sediment sample was taken from the modern beach at Astwood Park. Bulk measurements on the beach sand give a $\Delta_{47}$ value of $0.7141 \%$, which is equivalent to a formation temperature of $18.7^{\circ} \mathrm{C}$. Bulk $\delta^{18} \mathrm{O}$ and $\delta^{13} \mathrm{C}$ values are consistent with a mixture of calcite and aragonite in equilibrium with modern seawater (Table 1).

\subsubsection{Bierman Quarry}

The Town Hill Fm. at Bierman Quarry exposes a Lower unit (MIS 11) and Upper unit (MIS 9) separated by a 10-20 cm thick red soil layer. All exposures are well above current sea level and above the influence of all prior sea level maxima. Thin sections of the Lower unit of the Town Hill Fm. show significant amounts of meteoric phreatic spar (18\% of rock) as well as 
vadose meniscus cements and thin, irregular crystalline rinds (29\%). Porosity (6\%) has been reduced by cement growth in inter-granular and dissolution porosity. The Upper Town Hill Fm. is significantly more porous at $24 \%$ porosity, and shows no sign of phreatic cementation in thin section. Extensive vadose alteration is present with dissolution apparent on many grains and vadose cements representing $24 \%$ of the remaining rock.

Whole rock $\Delta_{47}$ values for the Lower and Upper Town Hill Fm. at Bierman Quarry are $0.627 \%$ and $0.675 \%$, which correspond to 53.2 and $32.8{ }^{\circ} \mathrm{C}$, respectively. Microsampling of algal grains and phreatic cements in the lower unit and algal grains in the upper unit of the Town Hill Fm. shows that they have been altered by fresh water with $\delta^{18} \mathrm{O}$ values less than $-2 \%$ based on the combined measures of $\Delta_{47}$ and $\delta^{18} \mathrm{O}$ (Figure 4B).

\subsubsection{Devonshire Bay/Rocky Bay}

The Belmont Formation (MIS 7) in Devonshire and Rocky Bays forms a beach hardground approximately 2 meters above current sea level, which transitions upsection into eolianite dunes. An older set of Belmont eolianite dunes outcrops below the beachrock and are very heavily altered, with phreatic cement and neomorphic replacement accounting for over 50\% of the rock by volume. The overlying Belmont Fm. eolianite is very weakly cemented above the 2 meter mark, with very little phreatic cement and up to $16 \%$ vadose cements and silts. In Rocky Bay, the Rocky Bay Formation (MIS 5e) cuts down into the Belmont Fm., consisting of a cliffcut rubble section, a gastropod rich protosol, which is in turn overlain by the Rocky Bay Fm. eolianite approximately 3 meters above current sea level. The Rocky Bay Formation is significantly less well cemented than the Belmont Fm. beachrock in this locality and is easily friable, unlike the Belmont Formation.

Bulk $\Delta_{47}$ values for the older Belmont Fm. eolianite range from 0.695\% to 0.714\%, which corresponds to 18.9 to $25.4{ }^{\circ} \mathrm{C}$. Two of the samples, which have trace amounts ( 4\%) of vadose silt features, display elevated temperatures. Microsampling of allochems reveals that all of the grains that appear to be unaltered in thin section have $\delta^{18} \mathrm{O}$ values that are not representative of original material, and have been extensively altered by interaction with fresh water (Figure $4 \mathrm{C}$ ). A few cements have $\delta^{18} \mathrm{O}$ values more negative than $-5 \%$, which is more negative than calcite equilibrated with current rainfall (-4\% VPDB for calcite in equilibrium 
with rainfall, IAEA/WMO Global Network for Isotopes in Precipitation, 2014), so either precipitation patterns have changed or some other process is required to reach such negative values. The overlying Belmont Fm. beach has similar bulk $\Delta_{47}$ values as the older eolianite, with $\Delta_{47}$ values falling between $0.676 \%$ and $0.73 \%$. The two samples that display vadose features ( $15 \%$ of rock by volume) have lower $\Delta_{47}$ values, while the sample containing solely primary marine and meteoric phreatic material has higher $\Delta_{47}$ values. Microsampling of components shows that the original grains in the beachrock section have not been as uniformly altered with fresh water as in the older eolianite, with some syntaxial cements probably being marine in origin (Figure 4D). Some meteoric vadose features in the beachrock were large enough to be microsampled and fall in the range of the other components, with the exception of one vadose cement which had a $\delta^{18} \mathrm{O}$ of $-8.7 \%$ and is likely the result of kinetic fractionation.

\subsubsection{Horseshoe Bay}

Modern beach sediment was sampled at Horseshoe Bay. $\delta^{18} \mathrm{O}$ and $\delta^{13} \mathrm{C}$ values are consistent with calcite and aragonite in equilibrium with modern seawater, and $\Delta_{47}$ was $0.716 \%$, or $18.1^{\circ} \mathrm{C}$.

\subsubsection{Watch Hill Park}

Watch Hill Park is an erosional shoreline, where the host rock is the Upper Town Hill Fm., with pockets of the Belmont and Rocky Bay Fms. in erosional pits on the exposed surface. The Upper Town Hill Fm. in this location is composed of steeply dipping eolianite foresets, and was sampled 8 meters above present sea level. Thin section analysis shows that all grains are coated with a 0.02 to $0.03 \mathrm{~mm}$ thick crust of likely former marine cement, which now has been altered in a vadose setting. In a few places small amounts of sparry phreatic cement (3\% rock volume, compared to $43 \%$ vadose altered cement) can be observed.

Microsampling results from the Upper Town Hill Fm. show that both constituent grains as well as the encrusting cement have been altered by fresh water (Figure 4E), as they have $\delta^{18} \mathrm{O}$ values that are less than $-1.5 \%$, and $\delta^{13} \mathrm{C}$ values were more negative than marine conditions would permit. Bulk rock $\Delta_{47}$ was $0.640 \%$, or $47.2{ }^{\circ} \mathrm{C}$.

\subsubsection{Whalebone Bay}


Whalebone Bay features a beachrock made of the Upper Town Hill Fm. (MIS 9) which extends below present sea level, and is overlain by a sequence that reflects the environmental transition from beach, to protosol, and to eolianite dunes of the Rocky Bay Fm. Samples were taken at the northern point of the bay at the well-studied section of Vollbrecht and Meischner (1993). Samples of the Upper Town Hill Fm. come from the present intertidal zone, and the Rocky Bay Fm. eolianite was sampled about a meter above the resistant bench formed by the Upper Town Hill Fm. beachrock.

Thin section analysis of the Upper Town Hill Fm. beach shows two stages of encrusting marine cement coating most grains, each 0.01-0.02 mm thick. Some grains have been neomorphically replaced by calcite spar. Porosity is variable from $9-24 \%$, with muddy micrite, vadose pendants and menisci, and local occurrences of phreatic spar. The Upper Town Hill Fm. is very heterogeneous in this location, with point counting showing large variations in types of cement, neomorphic replacement, and porosity over distances of 0.5 meters or less. Isotopic analysis of microsampled components (Figure 4F) suggests that the encrusting cement is marine in origin, while the grains and phreatic spar show evidence of interactions and replacement in meteoric water. $\Delta_{47}$ values varied with the contents of the sample - a sample containing $49 \%$ vadose features had a $\Delta_{47}$ of $0.647 \%$, while samples consisting of all other material types averaged $0.718 \%$.

The Rocky Bay Fm. eolianite is much less cemented and altered than the underlying Town Hill Fm. beach, with $28 \%$ porosity and insignificant amounts of cement and observable alteration in thin section. Microsampling on algae and bivalve fragments within the eolianite show mostly original marine isotopic values, with the possibility of slight interactions with meteoric water after deposition. Bulk $\Delta_{47}$ values for the eolianite were $0.720 \%$, which yield an average temperature estimate of $16.8^{\circ} \mathrm{C}$.

\subsubsection{Wilkinson Quarry}

Wilkinson Quarry is the largest quarry on the island, and features the Walsingham Formation (MIS 13+) and the Lower Town Hill Fm. (MIS 11), which are separated by a red soil zone up to 0.7 meters thick in places. The Walsingham Fm. is quite variable in appearance in thin section, with various expression and abundance of vadose features, phreatic spar, dissolution 
voids, travertine, and neomorphic replacive spar. Generally, samples stratigraphically lower in the quarry show more extensive alteration compared to samples from upper sections. Samples from the quarry floor show several layers of fibrous cement, which is interpreted to be originally precipitated in a marine environment. Two samples of the Walsingham Fm. from the quarry floor were isotopically analyzed by microdrilling of components for $\delta^{18} \mathrm{O}$ and $\delta^{13} \mathrm{C}$ and $\Delta_{47}$ analysis. Algal grains as well as phreatic cement from the Walsingham Fm. reveal extensive alteration by fresh water, and exhibit a fairly uniform $\delta^{18} \mathrm{O}$ composition (Figure 4G). The two samples had very different $\Delta_{47}$ values, with the sample having $13 \%$ vadose features giving a value of $0.624 \%$, while the sample without significant vadose features had a $\Delta_{47}$ value of 0.726\% (Table 3).

The Upper Town Hill Fm. at Wilkinson Quarry is not as heavily altered as the Walsingham Fm., and possesses a smaller amount of intergranular cement. Cementation is patchy, with vadose menisci in most places, as well as large bladed (dogtooth) spar of meteoric phreatic origin in some pore spaces. Wilkinson Quarry is the only locality where meteoric phreatic alteration features were observed more than 8 meters above present sea level. These include spectacular dogtooth spar crystals up to $8 \mathrm{~cm}$ in length that were present in cavities near the top of the quarry. Microsampling of samples adjacent to this cavity showed very uniform isotopic values for both phreatic spar and algal grains that indicate alteration by meteoric water (Figure $4 \mathrm{G}$ ). $\Delta_{47}$ analysis gave a value of $0.707 \%$ for this sample, which only had primary marine and phreatic features.

\section{Discussion}

\subsection{Point Counting and Mixing Calculations}

Clumped isotope studies are challenging because of the large amount of material required for accurate, repeatable analysis ( 15-20 mg per sample, Huntington et al., 2009; Wacker et al., 2013; Defliese et al., 2015; Defliese and Lohmann, 2015). This sample size constraint means that most analyses are composed of bulk samples made up of multiple components, which is certainly the case for our samples. We used point counting and microsampling techniques to try to identify the percent contribution of each end member (primary marine, meteoric phreatic, and vadose components) to each overall bulk sample, such that these measurements can be used to 
separate the influences of each component from the bulk composition and account for the mixing effects on $\Delta_{47}$ (Table 3). This approach works well for samples that are fairly homogenous, or with samples with multiple phases whose abundance is greater than $>5 \%$ contribution by volume, but it can be difficult to obtain reasonable results when end-member contributions are small.

Some of our samples exhibit spatial heterogeneity that makes reconciling bulk results from $\Delta_{47}$ measurements with high resolution and point counting analysis difficult. Because we could not sample for $\Delta_{47}$ from the thin sections that were used for microsampling and point counting (bulk $\Delta_{47}$ sampling took place on the paired chips used for thin sections), there exists the possibility that the high resolution analysis does not accurately reflect the components in the bulk $\Delta_{47}$ samples. This is reflected in some of our estimates for $\delta^{18} \mathrm{O}, \delta^{13} \mathrm{C}$, and $\Delta_{47}$ for components that were not microsampled due to abundances smaller than the MicroMill could target; some of these estimates are clearly not geologically viable despite being necessary to achieve isotopic mass balance in our calculations. Meteoric vadose $\Delta_{47}$ values were calculated using mass balance and the mixing equations outlined in Defliese and Lohmann (2015), and were quite variable, with several samples showing evidence of 'anti-clumped' behavior (negative $\Delta_{47}$ values), indicating discrimination against ${ }^{13} \mathrm{C}_{-}{ }^{18} \mathrm{O}$ bonds within the carbonate lattice.

\subsection{Diagenetic Alteration of Original Grains}

Diagenesis is the alteration and/or replacement of primary carbonate allochems, through a process ranging from microscale dissolution and precipitation to wholesale dissolution and replacement by secondary cement precipitates (Swart, 2015). All diagenetic processes (excluding mechanical compaction) involve the interaction of water and results in changes in the petrologic fabric, mineralogic, and geochemical composition of the primary material. In samples of marine origin, this process is enhanced by the presence of marine-derived aragonite and magnesian calcites, that due their thermodynamic metastability, provide an internal mineralogical/geochemical drive that leads to the stabilization of the carbonate assemblage to low-magnesian calcites and/or dolomite process early in its burial history (Stehli and Hower, 1961; Land, 1970; James and Choquette, 1990; Swart, 2015). The central role of water in this process of stabilization is of importance, as the process of water-rock interaction leads to the progressive modification of the geochemical and isotopic character of samples from the primary 
marine compositions to phases in equilibrium with the diagenetic fluids (Land and Epstein, 1970; Lohmann 1988; James and Choquette, 1990). Microscale alteration can be impossible to detect using standard petrographic microscopy as primary structures and fabrics can be preserved, and in such cases is only revealed by geochemical or isotopic analysis (James and Choquette, 1990). Many of our Bermuda samples fall into this category, as isotopic microsampling on grains that appear to be unaltered shows that some feature geochemical indicators of replacement and rock/water interaction (Figure 5). This is most apparent in the older Bermuda samples, as they have had more time to interact with pore fluids and show the largest departure from modern beach sediment.

While many allochems in our samples no longer consist of the primary material, this is accounted for in our mixing calculations and estimated $\Delta_{47}$ values for the various components. The mixing calculations use empirically determined values of microsampled $\delta^{18} \mathrm{O}$ and $\delta^{13} \mathrm{C}$ components: the only assumption is the $\Delta_{47}$ value of the altered grains that visually appear to be original. We treated all allochem and diagenetic components separately based on the microsampling results. Samples that retain original grain $\delta^{18} \mathrm{O}$ and $\delta^{13} \mathrm{C}$ values reflecting primary seawater were treated as original and given a $\Delta_{47}$ value of $0.7201 \%$, while samples that have reset 'primary' grain $\delta^{18} \mathrm{O}$ and $\delta^{13} \mathrm{C}$ values were treated as part of the meteoric phreatic component in our calculations and given a $\Delta_{47}$ value of $0.7175 \%$. This should not significantly affect our results, as the difference between the two values is $0.0026 \%$, which is practically negligible and well within the average measurement error of $0.0062 \%$ for $\Delta_{47}$.

\subsection{Meteoric Phreatic Cements as Recorders of Mean Annual Temperature}

Meteoric phreatic cements develop below the water table in a fresh water lens in pores that are continuously filled by fluid. On an island as small as Bermuda, the elevation of the water table relative to sealevel is negligible. A first order change in sea level is required to raise water table significantly; and thus, increase the stratigraphic level of carbonate sequence that is effected by meteoric phreatic diagenesis. (Figure 6, Meischner et al., 1995; Vollbrecht and Meischner, 1996). All of our sample outcrops occur at or above current sea level in Bermuda, requiring that a combination of glacial eustacy and/or tectonic movement to raise the sea level to elevations higher than present. Several beach outcrops in Bermuda are recognized to exist at levels above current sea level despite forming during intervals when ice volume was greater than 
469

470

471

472

473

474

475

476

477

478

479

480

481

482

483

484

485

486

487

488

489

490

491

492

493

494

495

496

497

498

499

present (Rowe et al. 2014), so higher relative sea level in Bermuda is not necessarily linked to warmer global temperatures. $\Delta_{47}$ values from samples that exhibit significant meteoric phreatic cements and alteration and are without significant $(<2 \%)$ vadose features vary from 0.7072 to $0.7298 \%$, which records a range in temperatures of 13.6 to $21.1{ }^{\circ} \mathrm{C}$. Average temperatures for phreatic samples were $17.3{ }^{\circ} \mathrm{C}$, which is very close to the average temperature of $16.8{ }^{\circ} \mathrm{C}$ recorded in unaltered Bermudan rocks and sediments. These temperatures are all below current MAT (Bermuda Weather Service, 2014), however reconstructed sea surface temperatures from ocean cores in the nearby Bermuda Rise suggest that current MAT is the warmest since MIS 5e, and that temperatures in this region were typically $\sim 4$ degrees colder than present, with some cold periods being up to 6-8 degrees colder (Sachs and Lehman, 1999; Lehman et al., 2002). Our samples fit this pattern, as all our samples are on average $4.7^{\circ} \mathrm{C}$ colder than present MAT.

Pure meteoric phreatic cement samples from Barbados do not fall as close to current MAT as Bermuda samples. All Barbados samples fall below $22.2{ }^{\circ} \mathrm{C}$, and average $19.0^{\circ} \mathrm{C}$, which is 7.2 degrees below the current MAT of $26.2^{\circ} \mathrm{C}$ (Barbados Meteorological Services, 2014). This may be partially explained by the differences in groundwater conditions between Bermuda and Barbados, as Barbados has a more complicated history of submergence and uplift than Bermuda. Barbados sits near a convergent plate boundary, and has been continually uplifted throughout the Pleistocene, which has produced the stepped coral terraces on the southwest shore (Schellman and Radtke, 2004). Barbados also has many current perched aquifers, streams, and natural springs indicative of a modern elevated water table in many parts of the island, , indicating that sea level is not necessarily the primary control on the water table(s) in Barbados, unlike Bermuda. The constant uplift history and modern evidence for higher water tables in Barbados makes it difficult to constrain the timing of Barbados phreatic diagenesis, as phreatic cements could form during both glacial and interglacial climates. $\Delta_{47}$ values from Barbados phreatic calcites suggest that most of them formed at times when the MAT was cooler than present, which would be consistent with the theory that phreatic diagenesis in Barbados is not confined to interglacial time periods. Oxygen isotope and $\mathrm{Mg} / \mathrm{Ca}$ evidence suggests that much of the Carribbean was $2-3{ }^{\circ} \mathrm{C}$ colder than present during much of the Pleistocene (Emiliani, 1966; Schmidt et al. 2006), with temperatures for the last glacial maximum thought to be up to 5 degrees colder than present. Our $\Delta_{47}$ values are likely biased towards cooler intervals, as much more time has passed in glacial conditions as opposed to interglacial during the Pleistocene (eg 
Emiliani, 1966), which means that the volume of cement formed during cooler times is likely to predominate. Mixing of multiple generations of cement into a single measurement also could be contributing to our higher than present $\Delta_{47}$ values, as small variations in $\delta^{18} \mathrm{O}$ coupled with larger variations in $\delta^{13} \mathrm{C}$ typical of freshwater diagenetic systems can easily cause apparent temperature offsets of 2-3 degrees colder than actual precipitation temperatures (Defliese and Lohmann, 2015). The combination of cooler temperatures during much of the Pleistocene and mixing offsets is the likely cause for such cold temperatures in Barbados.

While $\Delta_{47}$ results from Barbados are harder to reconcile with past temperatures, Bermuda $\Delta_{47}$ results show that meteoric phreatic cements and original unaltered grains record very similar temperatures, which is consistent with a diagenetic model where phreatic cements are formed preferentially during highstands. Based on these findings, we believe that phreatic cements in Bermuda are forming in isotopic equilibrium with MAT, and provide a reliable paleothermometry proxy.

Our choice of $\Delta_{47}$-temperature calibration undoubtedly affects the implications of this study, but we feel use of the Defliese et al. (2015) calibration is justified as the data in this study was generated using similar technique and operating conditions as the various datasets incorporated in that study. Use of the Ghosh et al. (2006) or similar calibration produces the opposite paleoclimatic conclusion, that temperatures in Bermuda were much warmer $\left(\sim 25^{\circ} \mathrm{C}\right)$ in the past, while Barbados temperatures are approximately the same as present. This raises concerns with the fossil record, as there are very few corals within the rock record in Bermuda. If temperatures in Bermuda were significantly warmer than present, coral should make up a much larger component of the rock record similar to Barbados, but this has not occurred.

\subsection{Vadose Disequilibrium and Kinetic Fractionation}

Based only on bulk $\Delta_{47}$ results from Bermuda samples, it is clear that all samples that contain $>2 \%$ vadose component are biased towards lower $\Delta_{47}$ values, and higher apparent precipitation temperatures (Figure 7). When point counting and microsampling data are taken into consideration, calculated vadose end member $\Delta_{47}$ values are always less than $0.5655 \%$, corresponding to apparent formation temperatures in excess of $86^{\circ} \mathrm{C}$, with some samples exhibiting much higher temperatures. These values cannot represent equilibrium fractionation 
and precipitation processes in Bermuda, as there is no conceivable scenario in which Bermuda sediments have been heated to such temperatures. There has been no volcanic activity in the area for $33 \mathrm{Ma}$ (Reynolds and Aumento, 1974), and processes such as solar heating from direct sunlight cannot be responsible for such high temperatures (Quade et al., 2013). Likewise, these samples have not been buried more than a few tens of meters at the most, so burial heating and re-equilibration (Passey and Henkes, 2012; Henkes et al., 2014) also cannot explain the anomalously low $\Delta_{47}$ values. Mixing offsets are also not large enough to have caused such dramatic departures from equilibrium formation temperatures. Calculated water $\delta^{18} \mathrm{O}$ values for samples affected by vadose diagenesis further point to non-equilibrium precipitation when compared to phreatic cements, as water $\delta^{18} \mathrm{O}$ values for vadose-affected samples are almost always positive. This cannot reflect equilibrium with meteoric waters in Bermuda, as modern precipitation has values close to $-3 \%$ (IAEA/WMO, 2014), similar to the values recorded in phreatic cements. Since vadose and phreatic cements are formed in waters of the same source, they should have similar calculated water $\delta^{18} \mathrm{O}$ values if they both represent equilibrium.

The only remaining explanations for such low $\Delta_{47}$ values are kinetic fractionation occurring during the precipitation process, and the preservation of inherited non-equilibrium $\Delta_{47}$ values in dissolved inorganic carbon within the vadose cements. The vadose zone is subject to several processes, such as $\mathrm{CO}_{2}$ degassing and diffusion through small pore spaces (James and Choquette, 1990; Eiler and Schauble, 2004; Quade et al., 2013), that may potentially cause kinetic effects, one or more of which is being recorded in the $\Delta_{47}$ signal. Infiltrating precipitation carries significant amounts of dissolved $\mathrm{CO}_{2}$ from soil organic matter down through the vadose zone, where reactions with host carbonate can rapidly occur before isotopic equilibrium is reached. Evaporation and $\mathrm{CO}_{2}$ degassing to air filled pore spaces causes precipitation to occur in the vadose zone, while also further driving dissolved inorganic carbonate species away from isotopic equilibrium (eg, Affek, 2013; Affek and Zaarur, 2014). The small, constricting, and highly variable pore spaces within the host rock can also contribute to biases in ${ }^{13} \mathrm{C}-{ }^{18} \mathrm{O}$ bonds through gas-phase diffusion, as pores may be isolating or restricting the free movement of gas throughout the rock, imparting kinetic fractionations (Eiler and Schauble, 2004). Recent works have shown that rapid precipitation of carbonate minerals can inherit disequilibrium $\Delta_{47}$ values from multiple dissolved $\mathrm{CO}_{3}{ }^{2-}$ species (Affek, 2013; Affek and Zaarur, 2014; Tripati et al., 2015); such a process is likely happening in the vadose zone. Given the unique parameters 
560 (amount of precipitation, soil cover, porosity, etc) that accompany each individual cement

561 forming event (Breecker et al., 2009), a range of disequilibrium $\Delta_{47}$ values could occur in the

562 vadose zone despite a common temperature, thus precluding them from yielding meaningful

563 temperature data.

564

565

566

567

568

569

570

571

572

573

574

575

576

577

578

579

580

581

582

583

584

585

586

587

588

\subsection{Implications for Paleoclimate Studies}

$\Delta_{47}$ analysis of meteoric calcite cements reveals that phreatic cements have great promise as a paleothermometer, while vadose cements are problematic and should be avoided for temperature reconstructions. Samples from Bermuda and Barbados indicate that phreatic cement accurately records inferred mean annual temperatures, without being affected by some of the biases that can affect other proxies. The constant temperature and water saturation of the phreatic zone ensures that precipitation occurs slowly at isotopic equilibrium, without seasonal or other environmental effects that can influence other proxy materials. While we did not investigate other water saturated diagenetic environments, such as deeper burial and marine phreatic environments, they would likely behave in a similar manner as meteoric phreatic cements. The use of $\Delta_{47}$ thermometry on other types of phreatic and burial cements would greatly enhance the study of diagenetic systems, and allow better reconstructions of burial history and thermal regime. Meteoric calcite cements also offer the advantage of being relatively resistant to further dissolution and precipitation, as they consist of minerallogically stable lowmagnesian calcite which has replaced the complex array of metastable phases comprising the primary marine sediment.

The largest obstacle towards further application of meteoric phreatic cements as a paleoproxy is the matter of dating the exposure. Our Barbados samples illustrate the difficulty in dating the alteration of host rocks, as it is not clear as to when diagenesis may have occurred. Dating of phreatic diagenesis will remain an obstacle for many locations, and may preclude the use of phreatic cements as a proxy for MAT in situations where the timing of diagenesis cannot be constrained.

Disequilibrium $\Delta_{47}$ values recorded in vadose cements demonstrates that some proxy materials do not form at isotopic equilibrium, and enhanced precipitation rates are likely the culprit (Daëron et al., 2011; Affek, 2013; Affek and Zaarur, 2014; Tripati et al., 2015). Cement 
precipitation within the vadose zone occurs rapidly as $\mathrm{CaCO}_{3}$ solubility is lowered by a higher ionic concentration (evaporation of water), or rising $\mathrm{pH}\left(\mathrm{CO}_{2}\right.$ degassing) (Daëron et al., 2011), and dissolved inorganic carbon precipitates before isotopic exchange with water reaches isotopic equilibrium. Affek (2013) has shown that the amount of time required to reach isotopic equilibrium with respect to $\Delta_{47}$ is controlled by temperature, with reactions at $22{ }^{\circ} \mathrm{C}$ taking $12+$ hours to reach equilibrium. Given that our Bermudan vadose cements all display values that are clearly out of equilibrium with $\Delta_{47}$, it suggests that cement forming events in the vadose zone occur on very rapid timescales on the order of several hours, and are essentially finished before equilibrium is reached.

Vadose zone disequilibrium raises concerns about other common proxy materials that are used for $\Delta_{47}$ analysis that are driven by the same processes governing vadose precipitation. Both speleothems (Affek et al., 2008; Daëron et al., 2011; Kluge and Affek, 2012; Kluge et al., 2013; Kulge et al., 2014) and pedogenic carbonates (Passey et al., 2010; Suarez et al., 2011; VanDeVelde et al., 2013; Quade et al., 2013) have been extensively studied, with multiple attempts to address the documented offsets between known growth temperature and measured $\Delta_{47}$ temperatures (eg Kluge and Affek, 2012; Quade et al., 2013). Speleothems in particular have been shown to inherit non-equilibrium DIC $\Delta_{47}$ values caused by $\mathrm{CO}_{2}$ degassing and rapid precipitation (Daëron et al., 2011; Kluge and Affek, 2012; Kluge et al., 2013; Kluge et al., 2014), which has limited their application as a proxy for $\Delta_{47}$ analysis. Additionally, many pedogenic studies to date have reported unusually hot reconstructed temperatures, which are usually interpreted to reflect peak summer temperatures, and not mean annual temperatures (Passey et al., 2010; Quade et al. 2013; Peters et al. 2013). Whether effects similar to vadose zone disequilibrium extend to pedogenic carbonates is uncertain, but should be fully evaluated in future studies, given that precipitation in the soil zone is driven by $\mathrm{CO}_{2}$ degassing and evaporation, the same drivers affecting vadose precipitation.

\subsection{Implications for Pleistocene Temperatures}

Our results show that both Barbados and Bermuda were significantly colder than present for most of the Pleistocene. Temperatures on both islands were likely $\sim 5^{\circ} \mathrm{C}$ colder for much of the Pleistocene, confirming that the current interglacial regime is likely the warmest to have occurred in the last 500,000 years. Colder temperatures occur in unaltered rocks as well as 
phreatic cements from Bermuda, and suggest that Bermudan temperatures were likely colder than present even during warm intervals such as MIS 5e. Fossil evidence supports this conclusion, as coral reefs currently occur in Bermuda, but coral fragments make up very little of the older carbonate rocks and formations. Bermuda is currently near the northern limit of coral reefs today, and it is not difficult to imagine that cooler temperatures in the past would have prevented reef development.

7. Cooler temperatures from Barbados are more problematic, as traditionally it has been thought that the tropics are not as affected by glacial climates as latitudes closer to the poles. Our results suggest that Barbados has been significantly colder than present over much of the Pleistocene, perhaps averaging as much as $5-6{ }^{\circ} \mathrm{C}$ colder. Unfortunately our sampling did not include samples that contained unaltered material, so direct comparison with original $\Delta_{47}$ values is not possible for Barbados. Some of our results are undoubtedly due to mixing offsets, but they cannot account for more than 2-3 degrees of the $7.2^{\circ} \mathrm{C}$ separating our average reconstructed temperature from current MAT (Defliese and Lohmann, 2015). Based on the tight correlation between original sediment and phreatic $\Delta_{47}$ values in Bermuda, we have no reason to believe that our results are biased, and conclude that Barbados was at least $5-6{ }^{\circ} \mathrm{C}$ colder than current MAT for much of the Pleistocene.Conclusions

Carbonate rocks from Bermuda and Barbados were analyzed to determine the effects of meteoric diagenesis on clumped isotope signals. A combination of thin section analysis and microsampling for $\delta^{18} \mathrm{O}$ and $\delta^{13} \mathrm{C}$ were used to characterize different cements and their origin, and show that phreatic cements likely record mean annual temperatures, while vadose cements are biased towards unrealistically hotter temperatures. Given that phreatic cements form slowly at mean annual temperature, and are insulated from temperature excursions by the host body of rock, they may be an ideal phase for climate reconstructions, particularly in deep geologic time.

Vadose cements are likely biased by kinetic fractionation caused by evaporation and $\mathrm{CO}_{2}$ degassing mechanisms, which causes precipitation of cements before isotopic equilibrium can be achieved. This raises concerns about other common proxy materials used in $\Delta_{47}$ analysis such as speleothems and pedogenic carbonates, as the processes which drive precipitation of carbonate are the same as those active in the vadose setting. Therefore, it is recommended that vadose 
649 related carbonate phases be avoided in future studies where paleotemperature reconstructions are 650 made.

651 Our results also show that Bermuda and Barbados were about $5-6{ }^{\circ} \mathrm{C}$ colder during much

652 of the Pleistocene. This confirms other work that has suggested that current MAT is higher for

653 the subtropics than any time in the last $500 \mathrm{ka}$, and suggests that much of the Pleistocene may

654 have been significantly colder in the tropics during glacial intervals than interglacials.

655 Acknowledgements

656 The authors would like to thank Lora Wingate, who provided assistance with stable isotope

657 measurements. This work was supported by NSF grant EAR 1123733 (KCL) and a GSA

658 graduate student research grant (WFD).

659

660

661

662

663

664

665

666

667

668

References

669

Affek H.P., Bar-Matthews M., Ayalon A., Matthews A., and Eiler J.M. (2008)

670

Glacial/interglacial temperature variations in Soreq cave speleothems as recorded by

671

"clumped isotope" thermometry. Geochimica et Cosmochimica Acta 72, 5351-5360.

672 
Affek H. P. (2013) Clumped isotopic equilibrium and the rate of isotope exchange between CO2 and water. American Journal of Science 313, 309-325.

Affek H. P. and Zaarur S. (2014) Kinetic isotope effect in $\mathrm{CO}_{2}$ degassing: Insight from clumped and oxygen isotopes in laboratory precipitation experiments. Geochimica et Cosmochimica Acta 143, 319-330.

Allan J. R., and Matthews R. K. (1982) Isotope signatures associated with early meteoric diagenesis. Sedimentology 29, 797-817.

Bergman S. C., Huntington K. W., and Crider J. G. (2013) Tracing paleofluid sources using clumped isotope thermometry of diagenetic cements along the Moab Fault, Utah. American Journal of Science 313, 490-515.

Breecker D. O., Sharp Z. D., and McFadden L. D. (2009) Seasonal bias in the formation and stable isotopic composition of pedogenic carbonate in modern soils from central New Mexico, USA. Geological Society of America Bulletin 121, 630-640.

Budd D. A., Frost E. L., Huntington K. W., and Allwardt P. F. (2013) Syndepositional Deformation Features In High-Relief Carbonate Platforms: Long-Lived Conduits for Diagenetic Fluids. Journal of Sedimentary Research, 83, 12-36.

Daëron M., Guo W., Eiler J., Genty D., Blamart D., Boch R., Drysdale R., Maire R., Wainer K., and Zanchetta G. (2011) 13C18O clumping in speleothems: Observations from natural caves and precipitation experiments. Geochimica et Cosmochimica Acta 75, 3303-3317.

Defliese W. F. and Lohmann K. C. (2015) Non-Linear Mixing Effects on Mass-47 CO $\mathrm{CO}_{2}$ Clumped Isotope Thermometry: Patterns and Implications. Rapid Communications in Mass Spectrometry 29, 901-909.

Defliese W. F., Hren M. T., and Lohmann K. C. (2015) Compositional and temperature effects of phosphoric acid fractionation on $\Delta_{47}$ analysis and implications for discrepant calibrations. Chemical Geology 396, 51-60.

Dennis K. J., Affek H. P., Passey B. H., Schrag D. P., and Eiler J. M. (2011) Defining an absolute reference frame for 'clumped' isotope studies of $\mathrm{CO} 2$. Geochimica et Cosmochimica Acta 75, 7117-7131.

Eiler J. M. (2007) "Clumped-isotope" geochemistry-The study of naturally-occurring, multiply-substituted isotopologues. Earth and Planetary Science Letters 262, 309-327.

Eiler J. M. (2011) Paleoclimate reconstruction using carbonate clumped isotope thermometry. Quaternary Science Reviews 30, 3575-3588. 
Emiliani C. (1966) Paleotemperature Analysis of Caribbean Cores P6304-8 and P6304-9 and a Generalized Temperature Curve for the past 425,000 Years. The Journal of Geology 74, 109-124.

Ghosh P., Adkins J., Affek H., Balta B., Guo W., Schauble E. A., Schrag D., and Eiler J. M. (2006) 13C-180 bonds in carbonate minerals: A new kind of paleothermometer. Geochimica et Cosmochimica Acta 70, 1439-1456.

Henkes G. A., Passey B. H., Grossman E. L., Shenton B. J., Pérez-Huerta A., and Yancey T. E. (2014) Temperature limits for preservation of primary calcite clumped isotope paleotemperatures. Geochimica et Cosmochimica Acta 139, 362-382.

Huntington K. W., Eiler J. M., Affek H. P., Guo W., Bonifacie M., Yeung L. Y., Thiagarajan N., Passey B., Tripati A., Daeron M., and Came R. (2009) Methods and limitations of 'clumped' CO2 isotope $(\Delta 47)$ analysis by gas-source isotope ratio mass spectrometry. Journal of Mass Spectrometry 44, 1318-1329.

Huntington K. W. and Lechler A. R. (2015) Carbonate clumped isotope thermometry in continental tectonics. Tectonophysics 647-648, 1-20.

IAEA/WMO (2014) Global Network of Isotopes in Precipitation. The GNIP Database. Accessible at: http://www.iaea.org/water

James N. P. and Choquette P. W. (1990) Limestones - The Meteoric Diagenetic Environment. In Diagenesis, (eds I. A. McIlreath and D. W. Morrow). Geological Association of Canada, St. John's, Newfoundland, pp. 35-74.

Kluge T. and Affek H. P. (2012) Quantifying kinetic fractionation in Bunker Cave speleothems using 4 47. Quaternary Science Reviews 49, 82-94.

Kluge T., Affek H. P., Marx T., Aeschbach-Hertig W., Riechelmann D. F. C., Scholz D., Riechelmann S., Immenhauser A., Richter D. K., Fohlmeister J., Wackerbarth A., Mangini A., and Spotl C. (2013) Reconstruction of drip-water $\delta^{18} \mathrm{O}$ based on calcite oxygen and clumped isotopes of speleothems from Bunker Cave (Germany). Climate of the Past 9, 377-391.

Kluge T., Affek H. P., Zhang Y. G., Dublyansky Y., Spotl C., Immenhauser A., and Richter D. K. (2014) Clumped isotope thermometry of cryogenic cave carbonates. Geochimica et Cosmochimica Acta 126, 541-554.

LAND L. S., MACKENZIE F. T., and GOULD S. J. (1967) Pleistocene History of Bermuda. Geological Society of America Bulletin 78, 993-1006.

Land L. S. (1970) Phreatic Versus Vadose Meteoric Diagenesis Of Limestones: Evidence From A Fossil Water Table. Sedimentology 14, 175-185. 
Land L. S. and Epstein S. (1970) LATE PLEISTOCENE DIAGENESIS AND DOLOMITIZATION, NORTH JAMAICA. Sedimentology 14, 187-200.

Lehman S. J., Sachs J. P., Crotwell A. M., Keigwin L. D., and Boyle E. A. (2002) Relation of subtropical Atlantic temperature, high-latitude ice rafting, deep water formation, and European climate 130,000-60,000 years ago. Quaternary Science Reviews 21, 19171924.

Lohmann, K. C. (1988) Geochemical patterns of meteoric diagenetic systems and their application to studies of paleokarst. In Paleokarst (Eds. N. P. James and P. W. Choquette). Springer New York, pp 58-80.

Loyd S. J., Dickson J. A. D., Scholle P. A., and Tripati A. K. (2013) Extensive, uplift-related and non-fault-controlled spar precipitation in the Permian Capitan Formation. Sedimentary Geology 298, 17-27.

Meischner D., Vollbrecht R., and Wehmeyer D. (1995) Pleistocene sea-level yo-yo recorded in stacked beaches, Bermuda south shore. Geological Society of America Special Papers 300, 295-310.

Passey B. H., Levin N. E., Cerling T. E., Brown F. H., and Eiler J. M. (2010) High-temperature environments of human evolution in East Africa based on bond ordering in paleosol carbonates. Proceedings of the National Academy of Sciences 107, 11245-11249.

Passey B. H. and Henkes G. A. (2012) Carbonate clumped isotope bond reordering and geospeedometry. Earth and Planetary Science Letters 351-352, 223-236.

Peters N. A., Huntington K. W., and Hoke G. D. (2013) Hot or not? Impact of seasonally variable soil carbonate formation on paleotemperature and $\mathrm{O}$-isotope records from clumped isotope thermometry, Earth and Planetary Science Letters 361, 208-218.

Quade J., Eiler J., Daëron M., and Achyuthan H. (2013) The clumped isotope geothermometer in soil and paleosol carbonate. Geochimica et Cosmochimica Acta 105, 92-107.

Reynolds P. H. and Aumento F. (1974) Deep Drill 1972. Potassium-Argon Dating of the Bermuda Drill Core. Canadian Journal of Earth Sciences 11, 1269-1273.

Rowe M. (1984) The freshwater "Central Lens” of Bermuda. Journal of Hydrology 73, 165-176.

Rowe M. P., Wainer K. A. I., Bristow C. S., and Thomas A. L. (2014) Anomalous MIS 7 sea level recorded on Bermuda. Quaternary Science Reviews 90, 47-59. 
Sachs J. P. and Lehman S. J. (1999) Subtropical North Atlantic Temperatures 60,000 to 30,000 Years Ago. Science 286, 756-759.

Schellmann G. and Radtke U. (2004) A revised morpho- and chronostratigraphy of the Late and Middle Pleistocene coral reef terraces on Southern Barbados (West Indies). EarthScience Reviews 64, 157-187.

Schmidt M. W., Vautravers M. J., and Spero H. J. (2006) Western Caribbean sea surface temperatures during the late Quaternary. Geochemistry, Geophysics, Geosystems 7, Q02P10.

Shenton B. J., Grossman E. L., Passey B. H., Henkes G. A., Becker T. P., Laya J. C., PerezHuerta A., Becker S. P., and Lawson M. (2015) Clumped isotope thermometry in deeply buried sedimentary carbonates: The effects of bond reordering and recrystallization, Geol. Soc. Am. Bull., (X), 1-16, doi:10.1130/B31169.1.

Stehli F. G. and Hower J. (1961) Mineralogy and early diagenesis of carbonate sediments. Journal of Sedimentary Research 31, 358-371.

Suarez M. B., Passey B. H., and Kaakinen A. (2011) Paleosol carbonate multiple isotopologue signature of active East Asian summer monsoons during the late Miocene and Pliocene. Geology 39, 1151-1154.

Swart P. K. (2015) The Geochemistry of Carbonate Diagenesis: The Past, Present, and Future. Sedimentology, in press.

VanDeVelde J. H., Bowen G. J., Passey B. H., and Bowen B. B. (2013) Climatic and diagenetic signals in the stable isotope geochemistry of dolomitic paleosols spanning the PaleoceneEocene boundary. Geochimica et Cosmochimica Acta 109, 254-267.

Vacher H. L., Hearty P. J., and Rowe M. P. (1995) Stratigraphy of Bermuda: Nomenclature, concepts, and status of multiple systems of classification. Geological Society of America Special Papers 300, 271-294.

Vacher H. L. and Rowe M. P. (1997) Chapter 2 Geology and hydrogeology of Bermuda. In Developments in Sedimentology (eds. H. L. Vacher and M. Q. Terrence). Elsevier, pp. 35-90.

Vollbrecht R. and Meischner D. (1993) Sea level and diagenesis: a case study on Pleistocene beaches, Whalebone Bay, Bermuda. Geol. Rundsch. 82, 248-262.

Vollbrecht R. Meischner D. (1996) Diagenesis in coastal carbonates related to Pleistocene sea level, Bermuda Platform. Journal of Sedimentary Research 66, 243-258. 
851 Wacker U., Fiebig J., and Schoene B. R. (2013) Clumped isotope analysis of carbonates: comparison of two different acid digestion techniques. Rapid Communications in Mass Spectrometry 27, 1631-1642. 
856 Table 1. $\Delta_{47}$ isotopic data for Bermuda. All errors are 1 standard error. We sorted each sample 857 into a different type classification based on thin section petrography, where $\mathrm{O}=$ original, $\mathrm{P}=$ 858 phreatic diagenesis, $\mathrm{V}=$ vadose diagenesis, and $\mathrm{V} / \mathrm{P}=$ vadose and phreatic diagenesis. For 859 sample localities, $\mathrm{HP}=$ Horseshoe Bay, AP = Astwood Park, WB = Whalebone Bay, $\mathrm{RB}=$ 860 Rocky Bay, DB = Devonshire Bay, BQ = Bierman Quarry, WHP $=$ Watch Hill Park, and WQ = 861 Wilkinson Quarry. 
863 Table 2. Stable isotope data for Barbados. All errors are one standard error. Barbados samples 864 represent $100 \%$ meteoric phreatic diagenesis.

865 
866 Table 3. Point counting, subsampling, and mixing calculation results for Bermuda samples.

867 Values in italics are derived from isotope mass balance and the mixing equations of Defliese and

868 Lohmann (2015), and were not measured directly. Samples are classified into different types

869 based on thin section petrography, where $\mathrm{O}=$ original, $\mathrm{P}=$ phreatic diagenesis, $\mathrm{V}=$ vadose

870 diagenesis, and V/P = vadose and phreatic diagenesis. For the mixing calculations, the original

871 component was assumed to have a $\Delta_{47}$ value of $0.7201 \%$, and phreatic cements having a $\Delta_{47}$

872 value of $0.7185 \%$ as discussed in the text. For sample localities, HP $=$ Horseshoe Bay, AP =

873 Astwood Park, WB = Whalebone Bay, RB = Rocky Bay, DB = Devonshire Bay, BQ = Bierman

874 Quarry, WHP = Watch Hill Park, and WQ = Wilkinson Quarry.

875 
876 Figure 1. Schematic diagram of the vadose and phreatic zones, along with processes and cement 877 textures.

878

879

880

881

882

883

884

885

886

887

888

889

890

891

892

893

894

895

896 
897 Figure 2. Bermuda stratigraphy and sampling locations. Geologic units follow the stratigraphy 898 and nomenclature of Vacher et al. (1995) and Vacher and Rowe (1997).

899

900

901

902

903

904

905

906

907

908

909

910

911

912

913

914

915

916

917 
918 Figure 3. Bermuda $\Delta_{47}$ temperatures plotted versus the age of host rock units, and sorted by the 919 types of diagenetic alteration observed.

920

921

922

923

924

925

926

927

928

929

930

931

932

933

934

935

936

937

938 
939 Figure 4. Plots of microsampled $\delta^{18} \mathrm{O}$ and $\delta^{13} \mathrm{C}$ from Bermuda, sorted by sampling locality. A)

940 Astwood Park B) Bierman Quarry C) Devonshire Bay/Rocky Bay older eolianite D)

941 Devonshire Bay/Rocky Bay younger samples E) Watch Hill Park F) Whalebone Bay G)

942 Wilkinson Quarry

943

944

945

946

947

948

949

950

951

952

953

954

955

956

957

958

959

960

961

962 
963 Figure 5. Plain polarized light thin section photos of various Bermuda rocks showing varying

964 degrees of diagenetic alteration. A) Sample B2011AP4, which is from the Southampton Fm. at 965 Astwood Park. There is very little cementation, and almost all original porosity remains. Scale 966 bar $=0.25 \mathrm{~mm}$. B) Sample B2011RB9, which is from the Belmont Fm. in Rocky Bay. Note 967 dissolution within algal grains, as well as vadose zone meniscus cements forming at grain 968 contacts. Scale bar $=0.25 \mathrm{~mm}$. C) Sample B2011DB9, which is from the older Belmont Fm. 969 eolianite in Devonshire Bay. Most (but not all) porosity is filled with phreatic calcite spar, with 970 many grains having dissolved out. Isotopic microsampling of algal grains that appeared to be 971 unaltered reveals that they have been altered by meteoric waters. Scale bar $=0.5 \mathrm{~mm}$. D)

972 Sample B2011DB5, which is from the younger Belmont Fm. beach section in Devonshire Bay. 973 Most aragonitic grains have been dissolved, with some exhibiting neomorphic replacement 974 which preserves structures (such as the bands in the bivalve fragment). Note the cement evenly 975 coating all grains, which was probably originally marine but is shown to be altered by meteoric 976 waters by isotopic microsampling. Scale bar $=1 \mathrm{~mm}$.

977

978

979

980

981

982

983

984

985

986

987

988

989

990 
991 Figure 6. The water table is controlled by relative sea level in Bermuda. During a lowstand, the 992 sample location lies in the vadose zone as there are no perched water tables in Bermuda. During 993 a highstand, raising sea levels raise the water table, so that the sample location lies in the phreatic 994 zone.

995

996

997

998

999

1000

1001

1002

1003

1004

1005

1006

1007

1008

1009

1010

1011 
1012 Figure 7. Bermuda samples plotted with $\Delta_{47}$ temperatures plotted versus $\%$ vadose composition. 1013 Higher \% vadose composition is associated with higher apparent $\Delta_{47}$ formation temperatures. 


\begin{tabular}{|c|c|c|c|c|c|c|c|}
\hline SAMPLE & Formation/Age (MIS) & Type & $\begin{array}{c}\text { Bulk } \delta^{13} \mathrm{C} \\
\text { (VPDB) }\end{array}$ & $\begin{array}{c}\text { Bulk } \delta^{18} \mathrm{O} \\
\text { (VPDB) }\end{array}$ & Bulk $\Delta_{47}$ & $\begin{array}{c}\text { Temperature } \\
\left({ }^{\circ} \mathrm{C}\right)\end{array}$ & $\begin{array}{l}\text { Water } \delta^{18} \mathrm{O} \\
\text { (VSMOW) }\end{array}$ \\
\hline B2011HB1 & Modern/1 & $\mathrm{O}$ & $1.55 \pm 0.03$ & $-0.30 \pm 0.03$ & $0.7164 \pm 0.0064$ & $18.0 \pm 2.1$ & $0.22 \pm 0.51$ \\
\hline B2011AP3 & Modern/1 & $\mathrm{O}$ & $0.72 \pm 0.02$ & $-0.35 \pm 0.01$ & $0.7141 \pm 0.0069$ & $18.7 \pm 2.3$ & $0.35 \pm 0.53$ \\
\hline B2011AP4 & Late Southampton/5a & $\mathrm{O}$ & $0.22 \pm 0.02$ & $-0.68 \pm 0.05$ & $0.7213 \pm 0.0077$ & $16.4 \pm 2.5$ & $-0.51 \pm 0.62$ \\
\hline B2011AP2 & Early Southampton/5a & $\mathrm{O}$ & $0.68 \pm 0.01$ & $-0.48 \pm 0.02$ & $0.7282 \pm 0.0061$ & $14.1 \pm 1.9$ & $-0.83 \pm 0.47$ \\
\hline B2011WB8 & Rocky Bay/5e & $\mathrm{O}$ & $0.27 \pm 0.04$ & $-0.49 \pm 0.03$ & $0.7203 \pm 0.0073$ & $16.7 \pm 2.4$ & $-0.25 \pm 0.57$ \\
\hline B2011RB9 & Belmont/7 & V & $0.68 \pm 0.01$ & $-1.03 \pm 0.01$ & $0.6952 \pm 0.0064$ & $25.3 \pm 2.3$ & $1.08 \pm 0.49$ \\
\hline B2011DB1 & Belmont/7 & $\mathrm{V} / \mathrm{P}$ & $-5.84 \pm 0.05$ & $-3.31 \pm 0.03$ & $0.6755 \pm 0.0051$ & $32.6 \pm 2.0$ & $0.27 \pm 0.42$ \\
\hline B2011DB5 & Belmont/7 & $\mathrm{P}$ & $-5.11 \pm 0.02$ & $-3.17 \pm 0.03$ & $0.7298 \pm 0.0062$ & $13.6 \pm 2.0$ & $-3.64 \pm 0.48$ \\
\hline B2011DB6 & Early Belmont/7 & $P$ & $-4.00 \pm 0.01$ & $-3.28 \pm 0.01$ & $0.7136 \pm 0.0075$ & $18.9 \pm 2.5$ & $-2.55 \pm 0.57$ \\
\hline B2011DB7 & Early Belmont/7 & V & $-4.15 \pm 0.01$ & $-3.41 \pm 0.03$ & $0.6952 \pm 0.0073$ & $25.3 \pm 2.6$ & $-1.30 \pm 0.57$ \\
\hline B2011DB8 & Early Belmont/7 & $\mathrm{P}$ & $-4.49 \pm 0.03$ & $-3.38 \pm 0.03$ & $0.7091 \pm 0.0062$ & $20.4 \pm 2.1$ & $-2.32 \pm 0.49$ \\
\hline B2011DB9 & Early Belmont/7 & $\mathrm{V}$ & $-4.27 \pm 0.04$ & $-3.33 \pm 0.02$ & $0.7077 \pm 0.0066$ & $20.9 \pm 2.3$ & $-2.16 \pm 0.51$ \\
\hline B2011BQ3 & Upper Town Hill/9 & $\mathrm{V}$ & $-3.12 \pm 0.01$ & $-2.63 \pm 0.02$ & $0.6753 \pm 0.0068$ & $32.7 \pm 2.6$ & $0.96 \pm 0.53$ \\
\hline B2011WHP1 & Upper Town Hill/9 & V & $-4.77 \pm 0.02$ & $-2.36 \pm 0.01$ & $0.6396 \pm 0.0064$ & $47.4 \pm 2.8$ & $3.92 \pm 0.50$ \\
\hline B2011WB1 & Upper Town Hill/9 & V & $-6.14 \pm 0.06$ & $-2.98 \pm 0.04$ & $0.6468 \pm 0.0056$ & $44.3 \pm 2.4$ & $2.76 \pm 0.46$ \\
\hline B2011WB2 & Upper Town Hill/9 & $\mathrm{P}$ & $-5.82 \pm 0.09$ & $-3.17 \pm 0.05$ & $0.7211 \pm 0.0048$ & $16.4 \pm 1.6$ & $-2.99 \pm 0.40$ \\
\hline B2011WB3 & Upper Town Hill/9 & $\mathrm{P}$ & $-2.89 \pm 0.02$ & $-2.48 \pm 0.08$ & $0.7154 \pm 0.0059$ & $18.3 \pm 2.0$ & $-1.89 \pm 0.51$ \\
\hline B2011BQ1 & Lower Town Hill/11 & $\mathrm{V} / \mathrm{P}$ & $-6.28 \pm 0.03$ & $-3.27 \pm 0.03$ & $0.6273 \pm 0.0055$ & $53.0 \pm 2.6$ & $3.92 \pm 0.44$ \\
\hline B2011WQ11 & Lower Town Hill/11 & $\mathrm{P}$ & $-6.78 \pm 0.01$ & $-2.99 \pm 0.03$ & $0.7072 \pm 0.0053$ & $21.1 \pm 1.8$ & $-1.77 \pm 0.43$ \\
\hline B2011WQ1 & Walsingham/13+ & $\mathrm{V} / \mathrm{P}$ & $-5.18 \pm 0.01$ & $-3.58 \pm 0.05$ & $0.6244 \pm 0.0056$ & $54.4 \pm 2.7$ & $3.84 \pm 0.47$ \\
\hline B2011WQ12 & Walsingham/13+ & $\mathrm{P}$ & $-5.76 \pm 0.02$ & $-3.65 \pm 0.04$ & $0.7259 \pm 0.0056$ & $14.9 \pm 1.8$ & $-3.83 \pm 0.46$ \\
\hline
\end{tabular}




\begin{tabular}{|c|c|c|c|c|c|c|}
\hline Sample & MIS & $\begin{array}{c}\text { Bulk } \delta^{13} \mathrm{C} \\
(\mathrm{VPDB})\end{array}$ & $\begin{array}{c}\text { Bulk } \delta^{18} \mathrm{O} \\
(\mathrm{VPDB})\end{array}$ & Bulk $\Delta_{47}$ & $\begin{array}{c}\text { Temperature } \\
\left({ }^{\circ} \mathrm{C}\right)\end{array}$ & $\begin{array}{l}\text { Water } \delta^{18} \mathrm{O} \\
\text { (VSMOW) }\end{array}$ \\
\hline Barbados 9 & $5 e$ & $-5.00 \pm 0.15$ & $-3.64 \pm 0.04$ & $0.7192 \pm 0.0065$ & $17.0 \pm 2.1$ & $-3.32 \pm 0.52$ \\
\hline Barbados 7 & $5 e$ & $-4.21 \pm 0.04$ & $-4.21 \pm 0.03$ & $0.7117 \pm 0.0054$ & $19.5 \pm 1.8$ & $-3.34 \pm 0.43$ \\
\hline WP-9-29MAR2010 Replaced Coral & 9 & $-3.13 \pm 0.05$ & $-4.20 \pm 0.03$ & $0.7214 \pm 0.0071$ & $16.3 \pm 2.3$ & $-4.04 \pm 0.56$ \\
\hline WP-9-29MAR2010 SPAR & 9 & $-4.50 \pm 0.20$ & $-4.35 \pm 0.01$ & $0.7177 \pm 0.0051$ & $17.5 \pm 1.7$ & $-3.92 \pm 0.38$ \\
\hline WP-19 & 11 & $-7.96 \pm 0.01$ & $-4.35 \pm 0.02$ & $0.7054 \pm 0.0063$ & $21.7 \pm 2.2$ & $-3.01 \pm 0.50$ \\
\hline St David's Float & 11 & $-1.17 \pm 0.10$ & $-4.23 \pm 0.02$ & $0.7040 \pm 0.0066$ & $22.2 \pm 2.3$ & $-2.78 \pm 0.51$ \\
\hline WP-07-07 & 11 & $-4.94 \pm 0.11$ & $-3.29 \pm 0.05$ & $0.7104 \pm 0.0052$ & $20.0 \pm 1.8$ & $-2.32 \pm 0.44$ \\
\hline WP-07-29MAR & 11 & $-5.08 \pm 0.12$ & $-3.45 \pm 0.02$ & $0.7144 \pm 0.0052$ & $18.6 \pm 1.7$ & $-2.78 \pm 0.41$ \\
\hline WP-07-26MAR & 11 & $-5.72 \pm 0.07$ & $-3.54 \pm 0.04$ & $0.7153 \pm 0.0059$ & $18.3 \pm 2.0$ & $-2.93 \pm 0.48$ \\
\hline WP-21 & 11 & $-9.85 \pm 0.17$ & $-4.47 \pm 0.11$ & $0.7142 \pm 0.0056$ & $18.7 \pm 1.9$ & $-3.79 \pm 0.52$ \\
\hline
\end{tabular}




\begin{tabular}{|c|c|c|c|c|c|c|c|c|c|c|c|c|c|}
\hline SAMPLE & Formation/Age (MIS) & Type & $\begin{array}{c}\text { Original } \\
\%\end{array}$ & $\begin{array}{c}\text { Phreatic } \\
\% \\
\end{array}$ & $\begin{array}{c}\text { Vadose } \\
\% \\
\end{array}$ & $\begin{array}{c}\text { Pore } \\
\text { Volume } \\
\% \\
\end{array}$ & $\begin{array}{c}\text { Original } \\
\delta^{18} \mathrm{O} \\
\end{array}$ & $\begin{array}{c}\text { Original } \\
\delta^{13} \mathrm{C} \\
\end{array}$ & $\begin{array}{c}\text { Phreatic } \\
\delta^{18} \mathrm{O} \\
\end{array}$ & $\begin{array}{c}\text { Phreatic } \\
\delta^{13} \mathrm{C} \\
\end{array}$ & $\begin{array}{c}\text { Vadose } \\
\delta^{18} \mathrm{O} \\
\end{array}$ & $\begin{array}{c}\text { Vadose } \\
\delta^{13} \mathrm{C} \\
\end{array}$ & $\begin{array}{c}\Delta_{47} \\
\text { (Vadose) }\end{array}$ \\
\hline B2011HB1 & Modern/1 & $\mathrm{O}$ & 100.0 & 0.0 & 0.0 & - & -0.30 & 1.55 & - & - & - & - & - \\
\hline B2011AP3 & Modern/1 & $\mathrm{O}$ & 100.0 & 0.0 & 0.0 & - & -0.35 & 0.72 & - & - & - & - & - \\
\hline B2011AP4 & Late Southampton/5a & $\mathrm{O}$ & 99.0 & 0.0 & 1.0 & 33 & -1.51 & 0.51 & - & - & - & - & - \\
\hline B2011AP2 & Early Southampton/5a & $\mathrm{O}$ & - & - & - & - & - & - & - & - & - & - & - \\
\hline B2011WB8 & Rocky Bay/5e & $\mathrm{O}$ & 98.0 & 1.0 & 1.0 & 28 & -0.57 & -0.28 & - & - & - & - & - \\
\hline B2011RB9 & Belmont/7 & $\mathrm{V}$ & 82.0 & 2.0 & 16.0 & 11 & -0.78 & -0.04 & - & - & -1.95 & -1.73 & 0.5655 \\
\hline B2011DB1 & Belmont/7 & $\mathrm{V} / \mathrm{P}$ & 43.0 & 43.0 & 13.0 & 8 & -2.27 & -6.27 & -2.72 & -6.12 & -6.21 & -8.92 & 0.3976 \\
\hline B2011DB5 & Belmont/7 & $\mathrm{P}$ & 22.0 & 77.0 & 2.0 & 17 & -3.77 & -6.04 & -3.32 & -6.28 & - & - & - \\
\hline B2011DB6 & Early Belmont/7 & $\mathrm{P}$ & 42.6 & 55.4 & 2.0 & 21 & -2.80 & -4.08 & -3.19 & -3.23 & - & - & - \\
\hline B2011DB7 & Early Belmont/7 & $\mathrm{V} / \mathrm{P}$ & 43.3 & 53.8 & 2.9 & 20 & -2.78 & -5.92 & -3.39 & -4.58 & -5.15 & -4.84 & -0.0450 \\
\hline B2011DB8 & Early Belmont/7 & $\mathrm{P}$ & 42.8 & 55.1 & 2.0 & 14 & -3.88 & -5.16 & -4.85 & -5.31 & - & - & - \\
\hline B2011DB9 & Early Belmont/7 & $\mathrm{V} / \mathrm{P}$ & 44.6 & 51.4 & 4.0 & 20 & -2.90 & -3.99 & -3.51 & -3.26 & -5.81 & -20.25 & 0.4178 \\
\hline B2011BQ3 & Upper Town Hill/9 & $\mathrm{V}$ & 75.8 & 0.0 & 24.2 & 24 & -1.78 & -2.98 & - & - & -5.29 & -3.56 & 0.5405 \\
\hline B2011WHP1 & Upper Town Hill/9 & $\mathrm{V}$ & 53.7 & 3.3 & 43.0 & 11 & -1.75 & -3.86 & -22.58 & -8.87 & -1.57 & -5.60 & 0.5277 \\
\hline B2011WB1 & Upper Town Hill/9 & $\mathrm{V}$ & 44.2 & 6.5 & 49.3 & 15 & -2.53 & -7.04 & -17.80 & -16.07 & -1.43 & -4.02 & 0.5487 \\
\hline B2011WB2 & Upper Town Hill/9 & $\mathrm{P}$ & 19.0 & 79.4 & 1.5 & 24 & -2.69 & -4.16 & -2.57 & -6.34 & - & - & - \\
\hline B2011WB3 & Upper Town Hill/9 & $\mathrm{P}$ & 33.4 & 65.2 & 1.4 & 9 & -2.13 & -4.08 & -1.19 & -2.52 & - & - & - \\
\hline B2011BQ1 & Lower Town Hill/11 & $\mathrm{V} / \mathrm{P}$ & 52.6 & 18.3 & 29.2 & 6 & -2.16 & -5.89 & -2.54 & -5.56 & -5.73 & -7.43 & 0.4017 \\
\hline B2011WQ11 & Lower Town Hill/11 & $\mathrm{P}$ & 36.0 & 63.3 & 0.8 & 13 & -2.33 & -7.33 & -2.38 & -7.57 & - & - & - \\
\hline B2011WQ1 & Walsingham/13+ & $\mathrm{V} / \mathrm{P}$ & 50.1 & 37.4 & 12.5 & 22 & -3.28 & -5.33 & -3.37 & -6.43 & -5.41 & -0.83 & -0.0171 \\
\hline B2011WQ12 & Walsingham/13+ & $\mathrm{P}$ & 35.8 & 62.6 & 1.6 & 11 & -3.34 & -5.47 & -3.82 & -5.92 & - & - & - \\
\hline
\end{tabular}




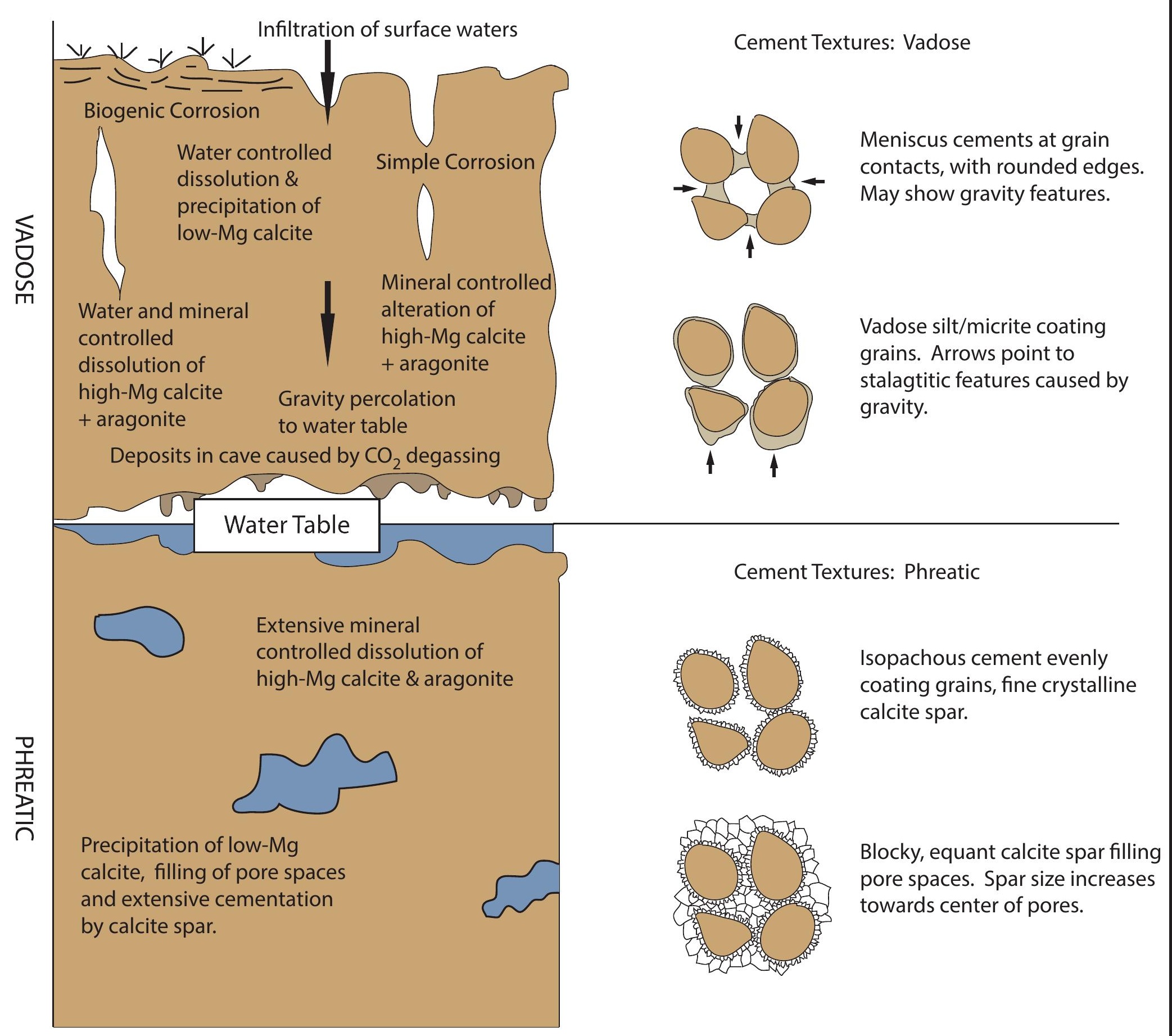




\section{Bermuda Geology and Sampling Locations} Lithostratigraphic Unit

MIS

Beach/Swamp

Southampton Fm

Rocky Bay Fm

Shore Hills Geosol

Belmont Fm

Ord Road Geosol

Town Hill Fm: Upper member 9

Harbour Road Geosol

Town Hill Fm: Lower member 11

Castle Harbour Geosol

Walsingham Fm

$13-26 ?$

1

$5 a$

$5 e$

7

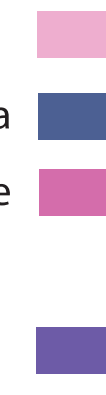

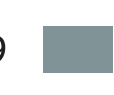
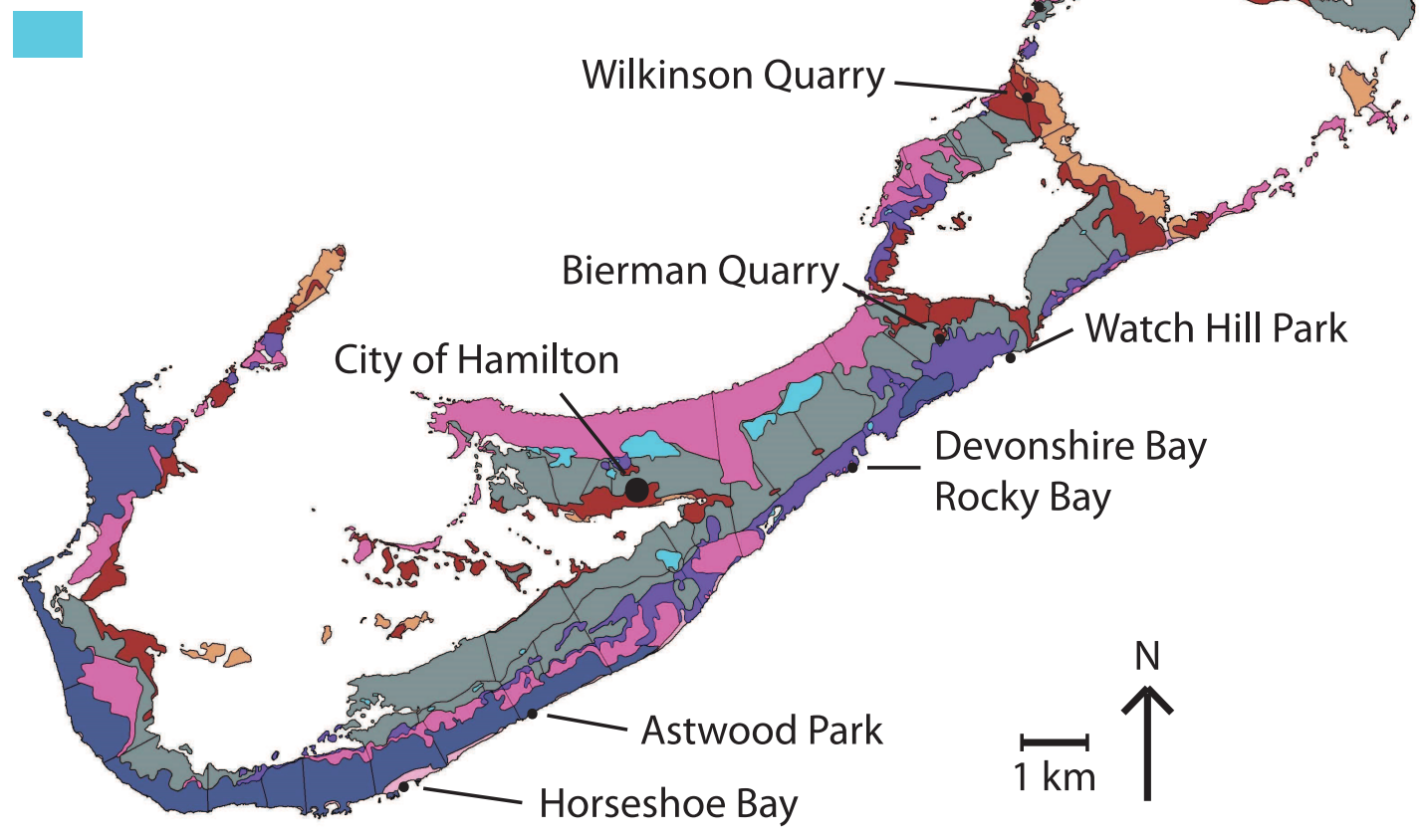
Figure 3

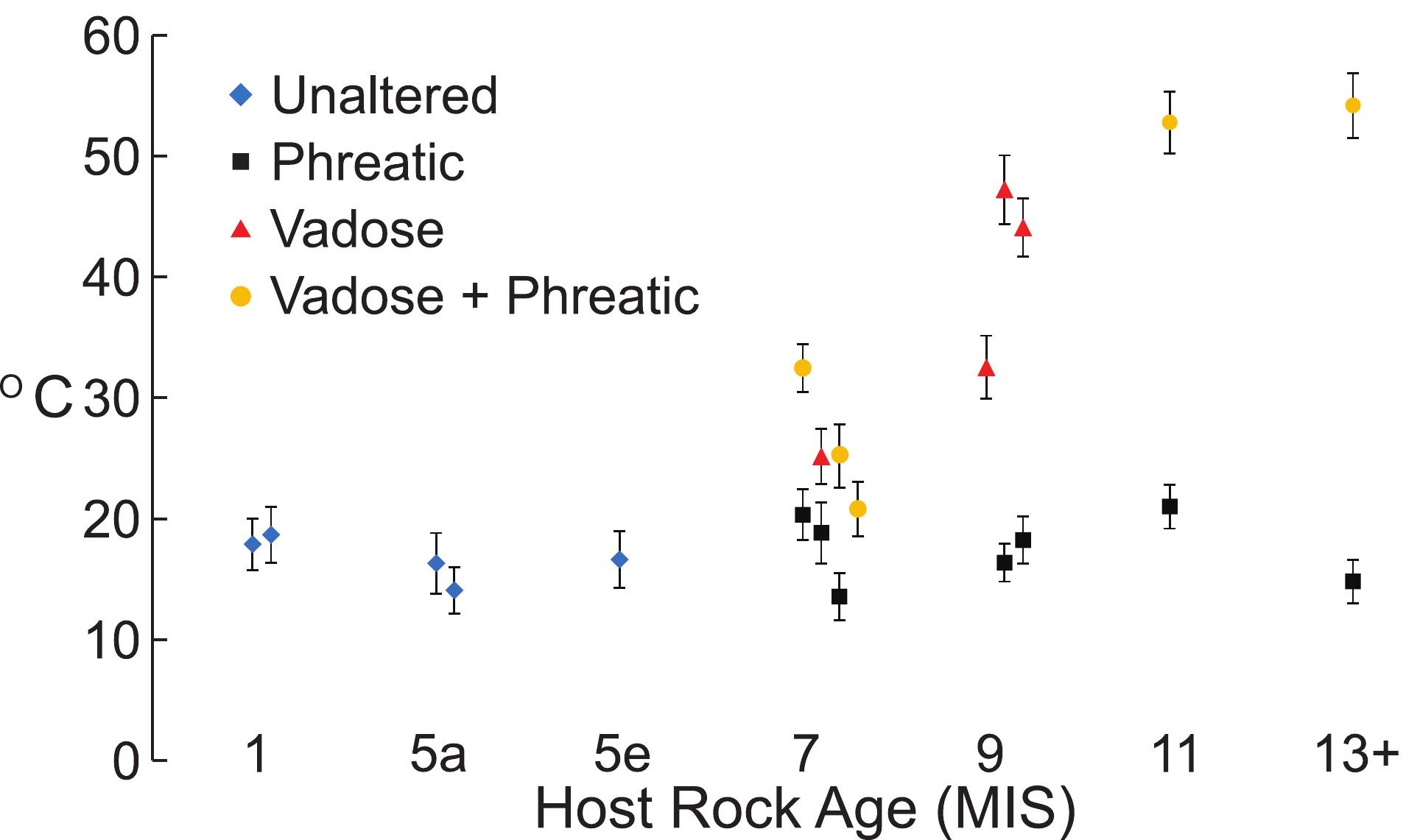

60

50- - Phreatic

- Vadose

- Vadose + Phreatic

$I$

10

0

$5 a$

$5 \mathrm{e}$

9

11

$13+$

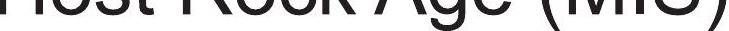

O 

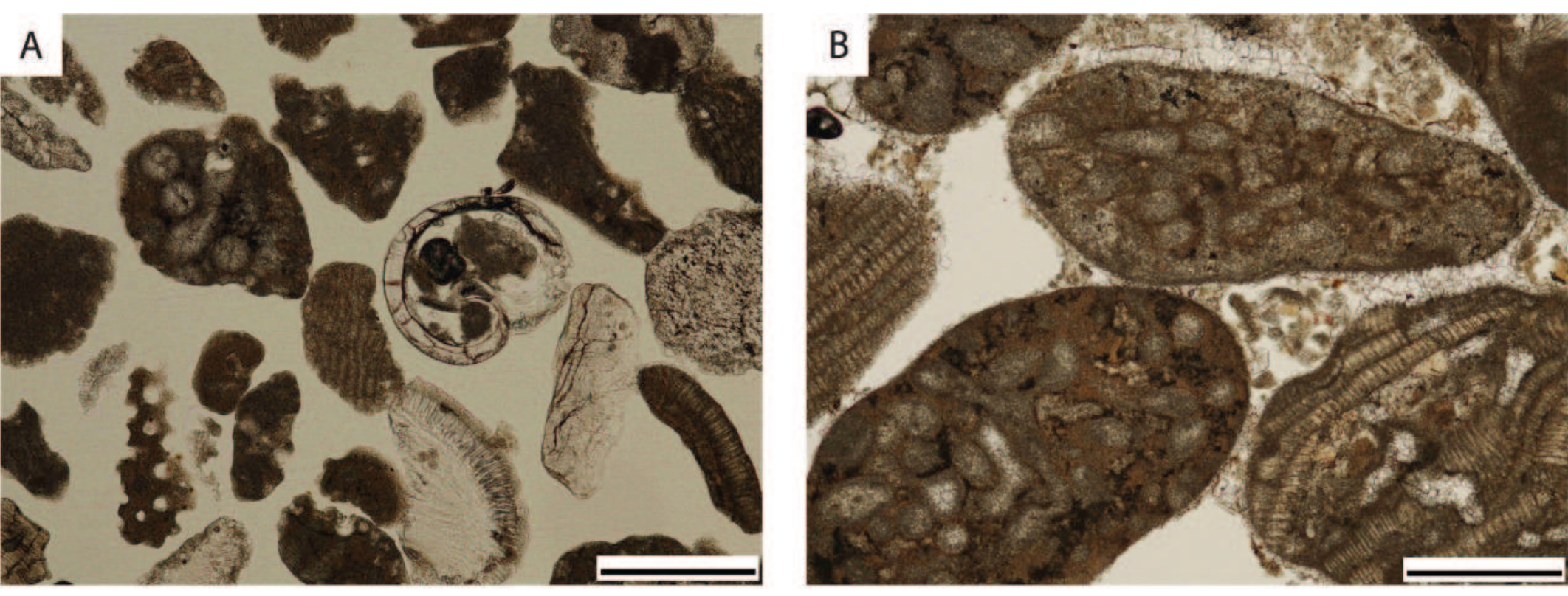

c 54 H
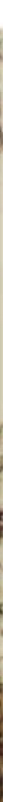

Figure 5

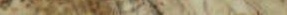


Figure 6

Glacial/Lowstand

Interglacial/Highstand

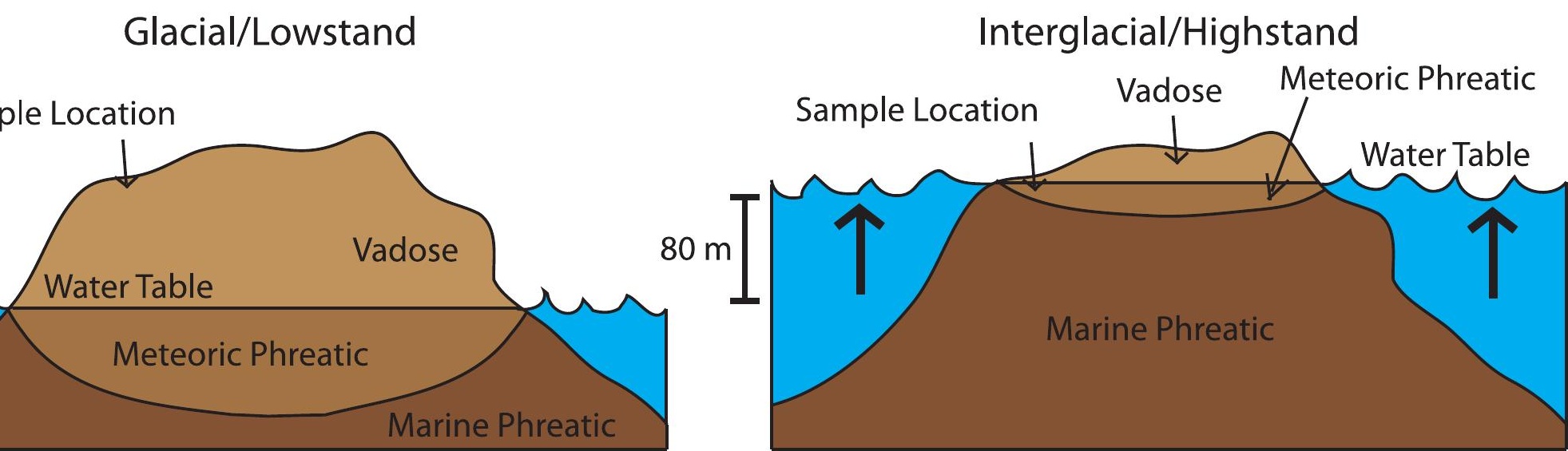

Sample Location 


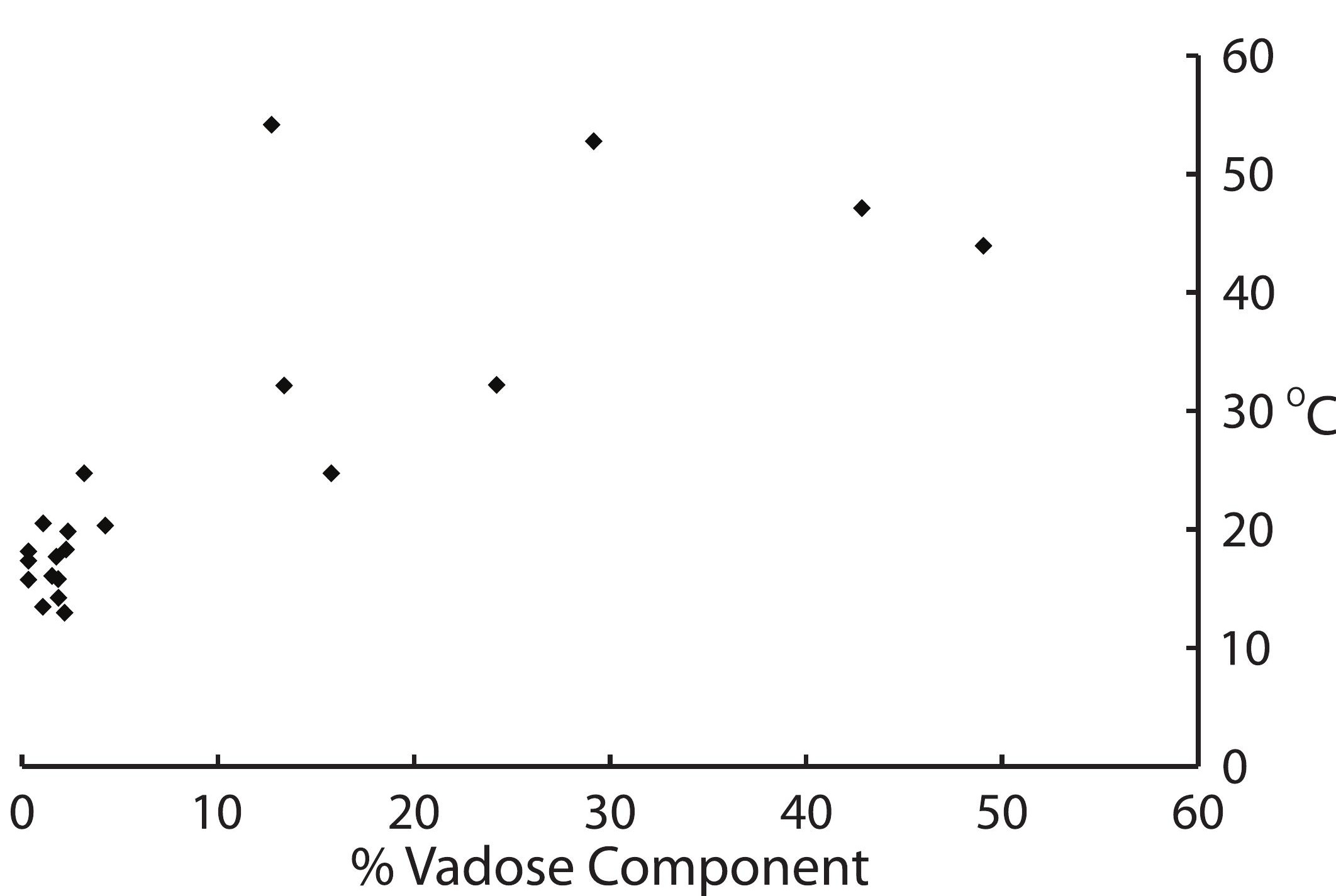

Figure 7

\section{Figure 7}

